Federal Reserve Bank of Dallas

Globalization and Monetary Policy Institute

Working Paper No. 120

http://www.dallasfed.org/assets/documents/institute/wpapers/2012/0120.pdf

\title{
Global Banks, Financial Shocks and International Business Cycles: Evidence from an Estimated Model
}

\author{
Robert Kollmann \\ ECARES, Université Libre de Bruxelles and CEPR
}

July 2012

\begin{abstract}
This paper estimates a two-country model with a global bank, using US and Euro Area (EA) data, and Bayesian methods. The estimated model matches key US and EA business cycle statistics. Empirically, a model version with a bank capital requirement outperforms a structure without such a constraint. A loan loss originating in one country triggers a global output reduction. Banking shocks matter more for EA macro variables than for US real activity. During the Great Recession (2007-09), banking shocks accounted for about $20 \%$ of the fall in US and EA GDP, and for more than half of the fall in EA investment and employment.
\end{abstract}

JEL codes: F36, F37, E44, G21

\footnotetext{
* Robert Kollmann, ECARES, CP 114, Université Libre de Bruxelles; 50 Av. Franklin Roosevelt, B-1050 Brussels, Belgium. 32-2- 650- 4474. robert_kollmann@yahoo.com. Matthias Paustian contributed to this project in its early stages--I thank him for his advice and for computer code. I also thank Werner Roeger for many discussions. Helpful comments and suggestions were also received from Gernot Müller, Alan Sutherland, Christoph Thoenissen, Ken West, Egon Zakrajšek and participants at several workshops. For financial support I thank the National Bank of Belgium, Université Libre de Bruxelles (Action de recherche concertée ARC-AUWB/2010-15/ULB-11) and the EU Commission (CEPR project 'Politics, Economics and Global Governance: The European Dimensions' funded by the EU Commission under its 7th Framework Programme for Research, Contract Nr. 217559.) The views in this paper are those of the author and do not necessarily reflect the views of the Federal Reserve Bank of Dallas or the Federal Reserve System.
} 


\section{Introduction}

The global financial crisis that erupted in 2007 revealed the fragility of major financial institutions, and it led to the sharpest global recession since the 1930s. These dramatic events require a rethinking of the role of financial intermediaries for real activity. Before the crisis, standard macro theory largely abstracted from financial intermediaries. The crisis has stimulated much research that incorporates banks in dynamic stochastic general equilibrium (DSGE) models. Given the global nature of the crisis, that research has frequently focused on open economy models; see, for example, Devereux and Sutherland (2011), Gamber and Thoenissen (2011), and Kollmann et al. (2011). ${ }^{1}$ In this new class of DSGE models, bank capital is a key state variable for domestic and foreign real activity - negative shocks to bank capital are predicted to increase the spread between banks' lending and deposit rates, and to trigger a fall in bank credit and real activity; with a globalized banking system, a loan loss originating in one country can thus lead to a worldwide recession.

So far, this new open economy macro-banking literature has used calibrated models--a systematic quantitative empirical assessment of the role of banks as a source of shocks and as a transmission channel in the global economy has not yet been presented. In order to provide such an assessment, the present paper estimates (using Bayesian methods) a two-country DSGE model with a global bank. Quarterly US and Euro Area (EA) macro data and banking data (bank loans, bank capital ratio and loan spread) for the period 1990-2010 are used. ${ }^{2}$

The model here assumes that each country is inhabited by a (representative) worker, an entrepreneur and a government. The global bank collects deposits from workers and makes loans to entrepreneurs, in both countries. The bank has to finance a fraction of her assets using equity (own funds). This constraint can reflect legal requirements and, more broadly, market pressures. It implies that the loan rate spread

\footnotetext{
${ }^{1}$ See also Correa et al. (2010), Davis (2010), Nguyen (2011), Andreasen et al. (2010), Perri and Quadrini (2011), Ueda (2011) and Van Wincoop (2011). Closed economy DSGE models with banks were, i.a., presented by Aikman and Paustian (2006), Van den Heuvel (2008), de Walque et al. (2010), Gertler and Kiyotaki (2011), Del Negro et al. (2011) and Kollmann et al. (2012a,b).

${ }^{2}$ Some previous papers have estimated open economy DSGE models, but those studies abstracted from banks. Two-country models were estimated by de Walque et al. (2005), Rabanal and Tuesta (2006) and Le et al. (2010) who also used UE and EA data, and by Jacob and Peersman (2011). Small open economy models were estimated by Adolfson et al. (2009) and Justiniano and Preston (2010).
} 
(relative to the deposit rate) is a decreasing function of bank capital, as the marginal benefit of bank capital is a decreasing function of bank capital. The estimated model assumes demand and supply shocks in home and foreign labor and good markets. In addition, there are stochastic loan losses (defaults) in the two countries, and shocks to the required bank capital ratio - henceforth, I refer to these shocks as 'banking shocks'.

The estimation results suggest that the bank capital requirement, and the banking shocks, matter for the dynamics of macro variables. A model with these ingredients outperforms model variants without an operative bank capital requirement or without banking shocks. According to the baseline model estimates, a one percentage point fall in the global bank capital ratio raises the loan rate spread by 44 basis points. An unanticipated US loan loss of 1 lowers both US and EA GDP by about $0.15 \$$, on impact. An unanticipated increase in the required bank ratio by one percentage point lowers US and EA GDP by $0.21 \%$, on impact.

The estimated model matches key cyclical properties of US and EA macro and banking variables. In particular, it captures the fact that US and EA loans are more volatile than output, and that loans are procyclical, while the loan spread is countercyclical. It also captures the fact that GDP, consumption, investment and bank loans are positively correlated across the US and the EA. Banking shocks matter more for EA macro variables than for US real activity. These shocks account for 5\%-10\% of US GDP volatility, and for $10 \%-25 \%$ of US investment and employment volatility. By contrast, banking shocks, explain $15 \%-30 \%$ of EA GDP volatility, $50 \%-70 \%$ of EA investment volatility, and $25 \%-50 \%$ of EA employment volatility.

Banking shocks played a noticeable role in the 2007-2009 'Great Recession', but were not the dominant factor driving the fall in GDP: according to the estimates, banking shocks accounted for about $20 \%$ of the fall in US and EA GDP during that recession; however, banking shocks accounted for more than half of the fall in EA investment and employment. During the previous US recession (2001) banking shocks also accounted for about $25 \%$ of the fall in US GDP and investment.

Section 2 presents the model. Section 3 discusses the econometric approach. Section 4 describes key data features. Section 5 reports the estimation results. Section 6 concludes. 


\section{A two-country world with a global financial intermediary}

In each of the two countries, called 'Home' $(\mathrm{H})$ and 'Foreign' $(\mathrm{F})$, there is a representative worker, an entrepreneur and a government. A global bank collects deposits from workers, and makes loans to entrepreneurs, in both countries. The bank faces a capital requirement: a fraction of bank assets has to be financed using the bank's own funds (equity). Entrepreneurs produce a homogenous tradable good that is used for consumption and for capital accumulation. All agents are infinitely-lived. Markets are competitive. Preferences and technologies have the same structure in both countries. The following exposition focuses thus on the Home country. Foreign variables are denoted by an asterisk.

\subsection{Preferences, technologies, markets}

The Home worker

The Home worker provides labor to the Home entrepreneur and invests her savings in one-period bank deposits. Her date $t$ budget constraint is:

$$
C_{t}^{W}+D_{t+1}+T_{t}^{W}=\omega_{t} N_{t}+D_{t} R_{t}^{D}
$$

where $C_{t}^{W}$ and $N_{t}$ are the worker's consumption and hours worked respectively. $\omega_{t}$ is the real wage rate. $D_{t+1}$ is the bank deposit held by the worker at the end of period $t . R_{t}^{D}$ is the gross interest rate on deposits, between $t-1$ and $t$. $T_{t}^{W}$ is a lump sum tax. The worker's date $t$ expected life-time utility, $V_{t}^{W}$, is:

$$
V_{t}^{W}=u\left(C_{t}^{W}\right)+\Psi^{D} u\left(D_{t+1}\right)-\Psi_{t}^{N} N_{t}+E_{t} \beta_{t+1}^{W} V_{t+1}^{W},
$$

with $u(x)=\frac{1}{1-\sigma}\left(x^{1-\sigma}-1\right), \quad \sigma>0$ and $\Psi^{D}>0$. The worker's marginal disutility of labor, $\Psi_{t}^{N}>0$, is an exogenous random variable. $\Psi_{t}^{N}$ will be referred to as the Home labor supply shock. Note that deposits provide utility to the worker (liquidity services). This ensures that, in equilibrium, the deposit rate is smaller than the loan rate, and that workers hold deposits while entrepreneurs borrow. The worker's subjective discount factor is decreasing in her future consumption: $\beta_{t+1}^{W} \equiv \beta^{W}\left(\overline{C_{t+1}^{W}}\right)$, with $0<\beta^{W}\left(\overline{C_{t+1}^{W}}\right)<1, \quad \beta^{W_{1}}\left(\overline{C_{t+1}^{W}}\right)<0$. The subjective discount factors of other agents are likewise decreasing functions of their 
own consumption. ${ }^{3}$ Agents treat their subjective discount factors as given, i.e. they do not internalize the effect of consumption on the discount factor-I thus write the argument of the subjective discount factor with an upper-bar. It is assumed that all agents have the same steady state rate of time preference, and the same risk aversion coefficient, $\sigma$.

The Home worker maximizes her life-time utility subject to the period-by-budget constraint (1). That decision problem has these first-order conditions:

$$
\begin{gathered}
u^{\prime}\left(C_{t}^{W}\right) \omega_{t}=\Psi_{t}^{N} \\
R_{t+1}^{D} E_{t} \beta_{t+1}^{W} u^{\prime}\left(C_{t+1}^{W}\right) / u^{\prime}\left(C_{t}^{W}\right)+\Psi^{D} u^{\prime}\left(D_{t+1}\right) / u^{\prime}\left(C_{t}\right)=1 .
\end{gathered}
$$

\section{The Home entrepreneur}

The Home entrepreneur accumulates physical capital and uses capital and local labor to produce output. Her technology is $Z_{t}=\theta_{t}\left(K_{t}\right)^{\alpha}\left(N_{t}\right)^{1-\alpha}, 0<\alpha<1$, where $Z_{t}, K_{t}$ and $N_{t}$ are output, capital and labor, respectively. Total factor productivity (TFP), $\theta_{t}>0$, is an exogenous random variable. The law of motion of capital stock is $K_{t+1}=(1-\delta) K_{t}+\Xi_{t} I_{t}$, where $0 \leq \delta \leq 1$ is the capital depreciation rate and $I_{t}$ is gross investment. $\Xi_{t}>0$ is an exogenous random shock to investment efficiency (Fischer (2006), Justiniano et al. (2008)). Gross investment is generated using output. Let $I \xi\left(I_{t} / I\right)$ be the amount of output needed to generate $I_{t}$, where $I$ is steady state investment, and $\xi$ is an increasing, strictly convex function with $\xi(1)=\xi^{\prime}(1)=1$. Henceforth, variables without time subscripts denote steady state values. The Home entrepreneur's period $t$ budget constraint is:

$$
L_{t} R_{t}^{L}-\Delta_{t}+\mathrm{I} \xi\left(I_{t} / I\right)+\omega_{t} N_{t}+d_{t}^{E}+T_{t}^{E}=L_{t+1}+\theta_{t}\left(K_{t}\right)^{\alpha}\left(N_{t}\right)^{1-\alpha},
$$

where $L_{t}$ is a one-period bank loan received by the Home entrepreneur in period $t-1 . R_{t}^{L}$ is the gross interest rate on that loan, set at $t-1$. In period $t$, the Home entrepreneur defaults by an exogenous random amount $\Delta_{t}$ on the amount $L_{t} R_{t}^{L}$ that she owes the bank. $T_{t}^{E}$ is a lump sum tax. $d_{t}^{E}$ is the entrepreneur's dividend income at $t$. The

\footnotetext{
${ }^{3}$ When subjective discount factors are constant, the model has a unit root (due to market incompleteness, transitory shocks then have permanent effects on the agents' relative wealth). The endogenous discount factors induce mean-reversion in individual wealth, and thus ensures stationarity (Kollmann (1991); Schmitt-Grohé and Uribe (2003)). The numerical solution method (local approximation) and the estimation method require stationarity.
} 
entrepreneur consumes her dividend income. Her expected lifetime utility at $t, V_{t}^{E}$, is: $V_{t}^{E}=u\left(d_{t}^{E}\right)+E_{t} \beta_{t+1}^{E} V_{t}^{E}$, with $\beta_{t+1}^{E}=\beta^{E}\left(\overline{d_{t+1}^{E}}\right)<1$. Utility maximization by the entrepreneur (subject to (4)) yields these first-order conditions:

$$
\begin{gathered}
\omega_{t}=(1-\alpha) \theta_{t} K_{t}^{\alpha} N_{t}^{-\alpha} \\
R_{t+1}^{L} E_{t} \beta_{t+1}^{E} u^{\prime}\left(d_{t+1}^{E}\right) / u^{\prime}\left(d_{t}^{E}\right)=1 \\
E_{t} \beta_{t+1}^{E}\left(u^{\prime}\left(d_{t+1}^{E}\right) / u^{\prime}\left(d_{t}^{E}\right)\right)\left\{\theta_{t+1} \alpha K_{t+1}^{\alpha-1} N_{t+1}^{1-\alpha}+q_{t+1}(1-\delta)\right\} / q_{t}=1, \text { with } q_{t} \equiv \xi^{\prime}\left(I_{t} / I\right) / \Xi_{t} .
\end{gathered}
$$

\section{The Home government}

At date $t$, the Home government makes exogenous random output purchases $G_{t}$ that are financed using lump sum taxes: $G_{t}=T_{t}^{W}+T_{t}^{E}+T_{t}^{B}$, where $T_{t}^{B}$ is a tax paid by the bank (see below). Each Home agent bears a constant share of the total Home tax burden, equal to her share in Home steady state consumption: $T_{t}^{i}=\lambda^{i} G_{t}^{i}$ for $i=W, E, B$ where $\lambda^{i}$ is timeinvariant. In setting taxes, the Home and Foreign governments assume that $50 \%$ of the banker's consumption takes place in country Home.

\section{The global bank}

The paper focuses on the role of bank capital for the transmission of macroeconomic and financial shocks to global real activity. The paper therefore adopts an aggregate perspective, and assumes a representative global bank that may be thought of as the global financial system. ${ }^{4}$ At $t$, the global bank receives deposits $D_{t+1}$ and $D_{t+1}^{*}$ from the Home and Foreign workers, respectively, and makes loans $L_{t+1}$ and $L_{t+1}^{*}$ to Home and Foreign entrepreneurs, respectively. Let $D_{t+1}^{W} \equiv D_{t+1}+D_{t+1}^{*}$ and $L_{t+1}^{W} \equiv L_{t+1}+L_{t+1}^{*}$ denote worldwide deposits and loans. The bank faces a capital requirement: her date $t$ capital

\footnotetext{
${ }^{4}$ Thus, the interbank market is not modeled here. Frictions in that market would matter for aggregate activity if they affected the total flow of funds from savers to borrowers. The model here captures empirical fluctuations in the loan spread and in the total volume of intermediation. To investigate the potential role of an interbank market, I studied a model variant with a savings bank and an investment bank. The savings bank gets deposits from households, and lends to the investment bank (interbank market), which lends to firms. Each bank faces a capital requirement and charges a loan spread. However, aggregate dynamics hinges on total bank capital--thus that set-up is observationally equivalent to the representative-bank model.
} 
$L_{t+1}^{W}-D_{t+1}^{W}$ should not be smaller than a fraction $\gamma_{t}$ of the bank's assets $L_{t+1}^{W}$. This may reflect a legal requirement or, more broadly, market pressures. ${ }^{5} \gamma_{t}$ is a random variable that is exogenous to the bank (see below). The bank can hold less capital than the required level, but this is costly. Let $x_{t} \equiv\left(L_{t+1}^{W}-D_{t+1}^{W}\right)-\gamma_{t} L_{t+1}^{W}=\left(1-\gamma_{t}\right) L_{t+1}^{W}-D_{t+1}^{W}$ denote the bank's 'excess' capital at the end of period $t$. The bank bears a cost $L^{W} \phi\left(x_{t} / L^{W}\right)$ as a function of $x_{t}$, where $L^{W}$ is the steady state stock of loans. $\phi$ is a convex function $\left(\phi^{\prime \prime} \geq 0\right)$ for which I assume: $\phi\left(x_{t}\right)>0$ for $x_{t}<0 ; \phi(0)=0$. Thus, for $x_{t}<0$ the bank incurs a positive cost; the cost is zero when the bank meets her capital requirement. At $t$, the bank also bears an operating cost $\Gamma \cdot\left(D_{t+1}^{W}+L_{t+1}^{W}\right)$, where $\Gamma>0$ is the (constant) real marginal cost of taking deposits and making loans. The bank's period $t$ budget constraint is:

$$
L_{t+1}^{W}+D_{t}^{W} R_{t}^{D}+\Gamma \cdot\left(D_{t+1}^{W}+L_{t+1}^{W}\right)+L^{W} \phi\left(x_{t} / L^{W}\right)+d_{t}^{B}+T_{t}^{B}+T_{t}^{B^{*}}=L_{t}^{W} R_{t}^{L}-\Delta_{t}-\Delta_{t}^{*}+D_{t+1}^{W},
$$

where $\Delta_{t}+\Delta_{t}^{*}$ is the bank's total loan loss, and $T_{t}^{B}+T_{t}^{B^{*}}$ is the total tax paid by the bank (in the two countries). $d_{t}^{B}$ is the profit (dividend) generated by the bank at $t$. (As the bank acts competitively, loan rates and deposit rates are equated across countries.) The banker consumes her dividend income. Her expected life-time utility at $t, V_{t}^{B}$, is:

$$
V_{t}^{B}=u\left(d_{t}^{B}\right)+E_{t} \beta_{t+1}^{B} V_{t+1}^{B}, \text { with } \beta_{t+1}^{B}=\beta^{B}\left(\overline{d_{t+1}^{B}}\right)<1 .
$$

The banker's utility maximization problem has these first-order conditions:

$$
\begin{gathered}
R_{t+1}^{D} E_{t} \beta_{t+1}^{B} u^{\prime}\left(d_{t+1}^{B}\right) / u^{\prime}\left(d_{t}^{B}\right)=1-\Gamma+\phi_{t}^{\prime}, \\
R_{t+1}^{L} E_{t} \beta_{t+1}^{B} u^{\prime}\left(d_{t+1}^{B}\right) / u^{\prime}\left(d_{t}^{B}\right)=1+\Gamma+\left(1-\gamma_{t}\right) \phi^{\prime}\left(x_{t} / L^{W}\right) .
\end{gathered}
$$

A linear approximation of these Euler equations gives:

$$
R_{t+1}^{L}-R_{t+1}^{D} \cong 2 \Gamma-\gamma_{t} \phi^{\prime}\left(x_{t} / L^{W}\right) \cong 2 \Gamma-\gamma_{t} \phi^{\prime}(0)-\gamma \phi^{\prime \prime}(0) \cdot\left(x_{t} / L^{W}\right) .
$$

Hence, the loan rate spread $R_{t+1}^{L}-R_{t+1}^{D}$ is a function of the required capital ratio $\gamma_{t}$ and of the bank's excess capital, $x_{t}$. Note that if the bank raises deposits and loans by one unit, then her operating cost rises by $2 \Gamma$ units; excess bank capital falls by $\gamma_{t}$, which raises the

\footnotetext{
${ }^{5}$ Bank capital requirements are often justified as limiting moral hazard in the presence of informational frictions and deposit insurance (see Freixas and Rochet (2008)). These issues are not explicitly modeled here. Instead, I take the capital requirement as given, and focus on its macroeconomic effects.
} 
penalty $L^{W} \phi\left(x_{t} / L^{W}\right)$ by $-\gamma_{t} \phi^{\prime}\left(x_{t} / L^{W}\right)$. The bank's Euler equations imply that the spread between the loan rate and the deposit rate $R_{t+1}^{L}-R_{t+1}^{D}$ covers the marginal cost $2 \Gamma-\gamma_{t} \phi^{\prime}\left(x_{t} / L^{W}\right)$. Under strict convexity of $\phi$ (i.e. $\left.\phi^{\prime \prime}>0\right)$, the marginal benefit of excess capital $-\phi^{\prime}$ is a decreasing function of (excess) bank capital, which implies that the loan rate spread is likewise a decreasing function of excess bank capital.

The sensitivity of the loan rate spread to changes in bank capital is governed by $\phi^{\prime \prime}$. Note that $x_{t} / L^{W} \cong c r_{t}-\gamma_{t}$, where $c r_{t} \equiv\left(L_{t+1}^{W}-D_{t+1}^{W}\right) / L_{t+1}^{W}$ is the bank's capital ratio, i.e. the ratio of bank equity to bank assets. A one percentage point rise in the capital ratio lowers the loan rate spread by $4 \gamma \phi^{\prime \prime}$ percentage points per annum (p.a.), while a one percentage point increase in the required bank capital ratio (holding constant $c r_{t}$ ) raises the spread by $4\left[\gamma \phi^{\prime \prime}-\phi^{\prime}\right]$ percentage points p.a..

\section{Market clearing}

Market clearing for the output good requires:

$Z_{t}+Z_{t}^{*}=C_{t}+C_{t}^{*}+d_{t}^{E}+d_{t}^{E^{*}}+d_{t}^{B}+I \xi\left(I_{t} / I\right)+I^{*} \xi\left(I_{t}^{*} / I^{*}\right)+G_{t}+G_{t}^{*}+L^{W} \phi\left(x_{t} / L^{W}\right)+\Gamma \cdot\left(L_{t+1}^{W}+D_{t+1}^{W}\right)$.

\section{Forcing variables}

Steady state TFP and investment efficiency are normalized to unity $\left(\theta=\theta^{*}=\Xi=\Xi^{*}=1\right)$.

There are 11 forcing variables: Home and Foreign TFP $\left(\theta_{t}, \theta_{t}^{*}\right)$, investment efficiency $\left(\Xi_{t}, \Xi_{t}^{*}\right)$, government purchases $\left(G_{t}, G_{t}^{*}\right)$, labor supply shocks $\left(\Psi_{t}^{N}, \Psi_{t}^{N^{*}}\right)$, loan losses $\left(\Delta_{t}, \Delta_{t}^{*}\right)$ and the required bank capital ratio $\left(\gamma_{t}\right)$. I refer to the first 8 shocks are 'nonbanking' shocks, and to the last three shocks as 'banking shocks'. A large number of nonbanking shocks is assumed so that the model has the potential to capture important features of macro data, even in the absence of banking shocks. Other recent estimated DSGE models likewise assume many shocks (e.g., Smets and Wouters (2007)).

Following the empirical DSGE literature, I assume that each 'non-banking' shock $Z_{t}$ follows a stationary univariate $\mathrm{AR}(1)$ process:

$$
\ln \left(z_{t} / z\right)=\rho^{z} \ln \left(z_{t-1} / z\right)+\varepsilon_{t}^{z},
$$


with $0 \leq \rho^{z}<1$, where $\varepsilon_{t}^{z}$ is a normally distributed white noise. The innovations to the non-bank shocks are correlated. Let $\varepsilon_{t}^{n b k}$ denote the vector of innovations to the 8 nonbanking shocks.

The laws of motion of loan losses (normalized by steady state GDP) and of the required bank capital ratio are:

$$
\begin{gathered}
\Delta_{t} / Y=\rho^{\Delta} \Delta_{t-1} / Y+\vartheta^{\Delta} \ln \left(Y_{t} / Y\right)+\varepsilon_{t}^{\Delta}, \quad \Delta_{t}^{*} / Y^{*}=\rho^{\Delta^{*}} \Delta_{t-1}^{*} / Y^{*}+\vartheta^{\Delta} \ln \left(Y_{t}^{*} / Y^{*}\right)+\varepsilon_{t}^{\Delta^{*}}, \\
\gamma_{t}=\left(1-\rho^{\gamma}\right) \gamma+\rho^{\gamma} \gamma_{t-1}+\vartheta^{\gamma} \ln \left(Y_{t}^{W} / Y^{W}\right)+\varepsilon_{t}^{\gamma},
\end{gathered}
$$

with $0 \leq \rho^{\Delta}, \rho^{\Delta^{*}}, \rho^{\gamma}<1 . Y_{t}, Y_{t}^{*}$ and $Y_{t}^{W} \equiv Y_{t}+Y_{t}^{*}$ are Home and Foreign GDP and world GDP respectively. ${ }^{6} \varepsilon_{t}^{\Delta}, \varepsilon_{t}^{\Delta *}$ and $\varepsilon_{t}^{\gamma}$ are normal white noises. $\varepsilon_{t}^{\Delta}$ and $\varepsilon_{t}^{\Delta *}$ are correlated, but independent of $\varepsilon_{t}^{\gamma} \cdot \varepsilon_{t}^{b k} \equiv\left(\varepsilon_{t}^{\Delta}, \varepsilon_{t}^{\Delta^{*}}, \varepsilon_{t}^{\gamma}\right)$ is assumed independent of the vector of nonbanking shocks, $\varepsilon_{t}^{n b k}$, at all leads and lags. To allow for correlation between $\left(\Delta_{t}, \Delta_{t}^{*}, \gamma_{t}\right)$ and the non-banking forcing variables, I assume that $\left(\Delta_{t}, \Delta_{t}^{*}, \gamma_{t}\right)$ depends on GDP and thus is partly endogenous. The independence of $\varepsilon_{t}^{n b k}$ and $\varepsilon_{t}^{b k}$ makes it straightforward to decompose the variance of the endogenous variables into components due to $\varepsilon_{t}^{n b k}$ and to $\varepsilon_{t}^{b k}$, respectively (see below).

\subsection{Model solution}

A linear approximation (around the deterministic steady state) is used to solve the model. The solution can be expressed as

$$
S_{t}=\Lambda_{1} s_{t-1}+\Lambda_{2} \varepsilon_{t},
$$

where $s_{t}$ is a vector consisting of states and controls chosen (or realized) in period $t$, expressed as deviations from steady state values. $\varepsilon_{t} \equiv\left(\varepsilon_{t}^{n b k}, \varepsilon_{t}^{b k}\right)$ is the vector of date $t$

\footnotetext{
${ }^{6}$ The bank's operating costs and the costs of excess bank capital $L^{W} \phi\left(x_{t} / L^{W}\right)$ represent inputs used by the bank; these costs thus have to be subtracted from the entrepreneurs' output when computing GDP. I assume that the resources used by Home banking $\Gamma \cdot\left(L_{t+1}+D_{t+1}\right)$ are purchased from the Home entrepreneur, and that $50 \%$ of the resource cost $L^{W} \phi\left(x_{t} / L^{W}\right)$ is likewise purchased from the Home entrepreneur. Hence, Home GDP is: $Y_{t} \equiv Z_{t}-\Gamma\left(L_{t+1}+D_{t+1}\right)-\frac{1}{2} L^{W} \phi\left(x_{t} / L^{W}\right)$.
} 
innovations to the forcing variables. $\Lambda_{1}$ and $\Lambda_{2}$ are matrices whose elements are functions of the model parameters.

\section{Econometric approach}

The model is estimated using quarterly time series for 12 macro and banking variables, in 1990q1-2010q3: US and EA GDP, total private consumption, investment, employment, commercial bank credit (deflated using the GDP deflator), the loan rate spread of US commercial banks, and the capital ratio of US commercial banks. The baseline estimates use data on total bank credit (to all sectors) by US Commercial banks and by EA Monetary financial institutions (MFI). Below, I also report estimation results that instead use data on credit to the business sector. (I use total credit for the baseline estimates, as that variable accounts for a greater share of bank assets.) The measure of the US loan rate spread is the series 'commercial and industrial loan rates spread over intended federal funds rate', from the Federal Reserve Board's (FRB) Survey of Terms of Business Lending (Table E.2). Data on the EA loan rate spread are only available for the period since 2003q1; as shown in Figure 2, the available EA loan spread closely tracks the US loan spread (correlation in 2003-2010: 0.90). ${ }^{7}$ I thus use the US loan rate spread as a measure of the global loan rate spread. The US Commercial bank capital ratio is taken as a proxy for the capital ratio of the global bank. The empirical bank capital ratio measure is constructed as (total financial assets - total liabilities)/total financial assets, using data from the Flow of Funds (FRB). See the Appendix for further information on the empirical variables. In estimation, the loan spread and the capital ratio are demeaned, while the other empirical variables are linearly detrended in log-form.

The number of data series used for estimation (12) exceeds the number of shocks (11). To avoid stochastic singularity of the model, I assume that observed variables contain measurement error. Allowing for measurement error also seems important because (especially) the empirical banking series might be imperfect measures of the

\footnotetext{
${ }^{7}$ The EA spread plotted in Fig. 2 is the difference between the EA MFI loan rate and the EONIA rate.
} 
theoretical concepts. ${ }^{8}$ The date $t$ data used in estimation, $y_{t}^{\text {obs }}$, are a subset of the states and controls included in the vector $S_{t}$ (see (11)), and are measured with error:

$$
y_{t}^{o b s}=\Gamma s_{t}+\mu_{t}
$$

where $\Gamma$ is a matrix, and $\mu_{t}$ is a vector of Gaussian i.i.d. measurement errors that are independent of the true state variables at all leads and lags. I use a Bayesian approach to estimate a subset of the parameters, while the remaining parameters are calibrated.

\subsection{Estimated and calibrated parameters}

I estimate the following parameters: the curvature of the bank capital penalty function $\phi^{\prime \prime}$, the curvature of the investment cost function $\xi "$, and the parameters of the process governing the banking shocks (9),(10). These parameters are key for the dynamic properties of the model, but do not affect the steady state. In addition, I estimate the risk aversion coefficient $\sigma$, and the standard deviations of measurement errors.

I calibrate the remaining parameters so that the steady state matches long run properties of the data. E.g. the technology parameter $1-\alpha$ is set at the mean empirical labor share, the steady state bank capital ratio is calibrated using historical mean capital ratios etc. It would be difficult to estimate these parameters through the lens of the model, unless ratios of the relevant variables were used in the measurement equation (as pointed out by Smets and Wouters (2007)). In addition, I calibrate the non-banking shock processes.

\subsubsection{Prior parameter distribution}

The means and standard deviations of prior parameter distributions are shown in Cols. (1)-(2) of Table 3. The mean of the prior distribution of $\sigma$ is set at unity. $\phi "$ affects the response of the loan rate spread to changes in the bank capital ratio, and is thus key for the transmission of banking shocks to real activity. Recall that a one percentage point

\footnotetext{
${ }^{8}$ To break the singularity, measurement error in just one observable is sufficient. To determine the presence of measurement error empirically, I allow for it in all series. Assuming measurement error just in banking variables gives the same results about the role of banking shocks. For recent empirical DSGE models that explicitly allow for measurement error see Ireland (2004), Boivin and Giannoni (2006), Gali et al. (2011) and de Antonio (2011).
} 
increase in the bank capital ratio lowers the loan rate spread by $4 \gamma \phi$ " percentage points per annum. As discussed below, I set the steady state required bank capital ratio at $\gamma=0.117$. I set the mean of the prior distribution at $4 \gamma \phi^{\prime \prime}$ at 0.2 , a value consistent with time series regressions of the loan rate spread on aggregate bank capital reported by Kollmann et al. (2011). Investment is excessively volatile when the capital accumulation technology is linear $(\xi "=0)$, as then international capital flows respond very rapidly to country-specific shocks. I set the mean of the prior distribution of $\xi "$ at 1 ; for that value, the ratio of the standard deviation of investment divided by the standard deviation of GDP is about 3 in the different model variants discussed below, and thus roughly in the range of the relative volatility of EA investment, when the other parameters are set at prior mean values. ${ }^{9}$

The priors of the parameters of the banking shock processes (9),(10) are set as follows: the prior mean of the standard deviations of $\varepsilon_{t}^{\Delta}, \varepsilon_{t}^{\Delta *}$ and $\varepsilon_{t}^{\gamma}$ is $0.5 \%$; the prior mean of the correlation between $\varepsilon_{t}^{\Delta}$ and $\varepsilon_{t}^{\Delta^{*}}$ and of the autoregressive coefficients $\rho^{\Delta}, \rho^{\Delta^{*}}, \rho^{\gamma}$ is 0.5 ; the prior mean of the GDP coefficients, $\vartheta^{\Delta}$ and $\vartheta^{\gamma}$, is $0 .{ }^{10}$ The prior mean of the standard deviation of $\varepsilon_{t}^{\Delta}, \varepsilon_{t}^{g *}$ and $\varepsilon_{t}^{\gamma}$ is in the range of estimated standard deviations of innovations to empirical measures of the non-banking shocks--see discussion below (e.g. the historical standard deviation of US and EA TFP innovations is $0.48 \%$, see Table 1). Empirically, TFP and other non-banking shocks (except the labor supply shock) are positively correlated across countries - the prior thus assumes that loan losses are likewise positively correlated across countries. The prior means and prior standard deviations of the standard deviations of measurement errors are set at $1 / 4$ and $1 / 20$, respectively, of the standard deviations of the corresponding (demeaned/detrended) empirical series.

\footnotetext{
${ }^{9}$ The prior distributions of $\sigma, \phi^{\prime \prime}$ and $\xi "$ are Gamma distributions with standard deviations set at half the prior means. Thus a reasonably wide range of parameter values around the mean has non-negligible mass.

${ }^{10}$ The prior standard deviations of these parameters are set at 0.1 .
} 


\subsubsection{Calibration}

Calibrated technology parameters (non-finance sector), size of government

One period in the model represents one quarter in calendar time. As is standard in the macro literature, the (quarterly) depreciation rate of physical capital is set at $\delta=0.025$. The elasticity of output with respect to capital is set at $\alpha=0.3$, consistent with long run average historical US and EA labor shares of about $70 \%$.

The two-country model here abstracts from US and EA trade with third countries;

I thus use the sum of US government consumption and of US net exports to countries other than the EA as an empirical measure of US 'autonomous' spending, $G_{t}$; EA autonomous spending is constructed analogously. During 1990-2010, US [EA] autonomous spending represented $14.2 \%$ of US GDP [21.2\% of EA GDP], on average. I take the US as the empirical counterpart of country 'Home' and set $G / Y=14.2 \%$, $G^{*} / Y^{*}=21.2 \%$

\section{Calibrated preference and bank parameters}

Most DSGE studies calibrate the subjective discount factor to match average historical returns. I use the same approach. As mentioned above, it is assumed that all agents have the same steady state subjective discount factor, here denoted by $\beta$. $\beta$ is set so that the steady state loan rate matches the mean 1990-2010 US real loan rate. I use the interest rate on 'commercial and industrial loans made by all commercial banks' reported by the FRB (Survey of Terms of Business Lending, Table E.2) as a measure of the nominal loan rate, from which I subtract the quarterly growth rate of the US GDP deflator to construct the real loan rate. The average US real loan rate $1990-2010$ was $3.440 \%$ p.a.. Accordingly, I set the (quarterly) steady state subjective discount factor at $\beta=0.9918$ (as $\beta R^{L}=1$, from the entrepreneur's Euler equation (6)).

I assume that all agents' subjective discount factors have the same elasticity with respect to consumption, denoted by $\varepsilon_{\beta}$. I set $\varepsilon_{\beta}$ at a small absolute value, $\varepsilon_{\beta}=-0.001$, that yields a stationary equilibrium, while generating (essentially) the same short run dynamics as a model variant with a constant subjective discount factor. (Impulse 
responses over the first 100 periods are very similar across model variants with $\varepsilon_{\beta}=0$ and $\left.\varepsilon_{\beta}=-0.001.\right)$

The sample mean (1990-2010) of the US loan rate spread was $2.161 \%$ p.a.. ${ }^{11}$ I set the steady state deposit rates in the model at $1.279 \%$ p.a., so that the steady state loan rate spread matches the mean historical spread, 2.161\%. The mean EA loan spread was 2.01\% in 2003-2010 (see above), which is close to the steady state spread assumed in the model calibration.

I set the steady state actual and required bank capital ratios at $c r=\gamma=11.17 \%$, which corresponds to the average capital ratio of US commercial banks during the sample period (from Flow of Funds data). The bank's Euler equations imply $R^{D} \beta=1-\Gamma+\phi^{\prime}$ and $R^{L} \beta=1+\Gamma+(1-\gamma) \phi^{\prime}$. Given the steady state deposit and loan rates, these two conditions pin down the bank's marginal operating cost $\Gamma$ and the steady state slope of the bank's 'penalty' function $\phi^{\prime}$ : $\Gamma=0.25 \%, \phi '=-0.28 \%$.

The assumption that $c r=\gamma$ implies that steady state excess bank capital is zero, $x=0$, i.e. $L^{W}(1-\gamma)=D^{W}$. I set $L(1-\gamma)=D$ and $L^{*}(1-\gamma)=D^{*}$, i.e. the steady state ratio of deposits to loans is the same in both countries (as is consistent with the data). The ratio of outstanding US commercial bank loans to annual US GDP was 53\% on average in 19902010, while the mean ratio of the stock of EA MFI loans divided by annual EA GDP was $87 \%$. Thus, the US has a noticeably lower loans/GDP ratio than the EA. The calibration reflects this: I assume that the steady state ratios of loans to annual GDP are $53 \%$ in country 'Home', and $87 \%$ in 'Foreign'. Finally, I assume that both countries have the same steady state GDP, normalized at unity: $Y=Y^{*}=1$. These steady state targets pin down the remaining preference parameters (the weights of deposits in Home and Foreign

\footnotetext{
${ }^{11}$ As mentioned above, the baseline measure of the US loan rate spread is the 'commercial and industrial loan rates spread over intended federal funds rate'. Using the rate on short term Certificates of Deposit as a measure of the bank's marginal funding costs yields a loan rate spread that has a 0.75 correlation with the baseline spread, and a sample mean of $1.929 \%$ p.a., which is close to the assumed steady state spread.
} 
workers' utility functions, $\Psi^{D}, \Psi^{D^{*}}$, and steady state marginal disutilities of labor, $\left.\Psi^{N}, \Psi^{N *}\right){ }^{12}$

\section{Calibrated 'non-banking' shock processes.}

I construct quarterly empirical measures of the 8 US and EA 'non-banking' forcing variables (1990-2010). Following Coeurdacier, Kollmann and Martin (2010), I use the ratio of the CPI to the investment deflator as a measure of investment efficiency. The empirical labor supply shock is constructed as $\Psi_{t}^{N}=(1-\alpha)\left(Z_{t} / N_{t}\right) / C_{t}$, which follows from the first order conditions (2),(5) when $\sigma=1$ (i.e. when $\sigma$ equals its prior mean). Thus, the empirical labor supply shock is proportional to labor productivity divided by consumption. ${ }^{13}$

I set the standard deviations, and auto- and cross-correlations of the non-banking shocks in the model equal to the corresponding moments of linearly detrended logs of the empirical measures (see Table 1). The empirical DSGE literature--that has largely focused on closed economies--typically assumes uncorrelated shocks, and it estimates the parameters of shock processes through the lens of the DSGE model (jointly with the remaining parameters). In a multi-country model it is important to allow for correlated shocks - empirical measures of the shocks are strongly correlated. I calibrate the process governing non-banking shocks, as empirical measures of the non-banking shocks can easily be constructed, and as estimation of the correlation matrix of these shocks through the lens of the model would be challenging (given the large number of crosscorrelations).

As reported in Table 1, US investment efficiency, US autonomous spending and the US labor supply shock are more volatile than the corresponding EA variables. The cross-country correlations of TFP (0.51) and investment efficiency (0.84) are sizable.

12 (3) implies $\Psi^{D}=\left(1-R^{D} \beta\right)\left(\left(C^{W} / Y\right) /(D / Y)\right)^{-\sigma} . D / Y$ is determined by $L / Y$, while $C^{W} / Y$ is pinned down by ratios of government purchases and investment to GDP. $Y=1$ then pins down $\Psi^{N}$ (as $\Psi^{N}$ determines the steady state labor input). In steady state, consumption by the Home [Foreign] worker and the entrepreneur represent respectively $58.2 \%$ and $4.8 \%$ [52.3\% and 3.5\%] of domestic GDP, while the banker's consumption represents $0.21 \%$ of world GDP.

${ }^{13}$ Labor productivity is constructed using GDP as a proxy for the entrepreneur's output $Z$. I also considered an alternative measure of the labor supply shock based on real wage rate data: $\Psi_{t}^{N}=\omega_{t} / C_{t}$. That measure gives similar estimates of model parameters and of the role of banking shocks. 
TFP is positively correlated with investment efficiency; US and EA TFP are strongly negatively correlated with US autonomous spending $(G)$, and negatively correlated with the US labor supply shock. All forcing variables are highly persistent (autocorrelations in the range $0.80-0.98)$.

\section{Data plots and business cycle statistics.}

Figure 1 plot the (demeaned/detrended) 12 empirical series used in estimation. Macro aggregates co-move closely across the US and the EA-the synchronicity was especially high during the recent 'Great Recession'. According to the NBER, that recession began in 2007q4 and ended in 2009q2. (Shaded areas in Figures indicate NBER recessions.) Relative to trend, US output fell by $8.5 \%$, during the recession, while EA output fell by $7.5 \%$; US consumption $(-7.3 \%)$ and investment $(-35.1 \%)$ fell more sharply than EA consumption (-4.0\%) and investment (-15.9\%). US and EA bank lending grew strongly in the years before 2008, and then collapsed sharply. The loan rate spread fell during the three years prior to the crisis, but rose sharply during the Great Recession. The bank capital ratio exhibits relatively mild fluctuations--throughout the sample period it stays in $\mathrm{a} \pm 2 \%$ range around the sample mean of $11.17 \%$.

Figures 3a-b plot the bank capital ratio, together with the baseline loan spread series and alternative spread measures that are used for robustness checks below (all series in Figures 3a-b are demeaned). Except for the period of the financial crisis, the bank capital ratio and the baseline loan rate spread comove negatively. While the loan rate spread rose, during the crisis (as mentioned above), the bank capital ratio has had a flat trend since about 2005--it has been argued that this may partly reflect accounting discretion, which has allowed banks to overstate the value of their assets in the crisis (Huizinga and Laeven (2009)). The correlation between the bank capital ratio and the baseline lending spread was -0.46 during the period 1990-2007, but close to zero $(-0.06)$ over the whole sample period (1990-2010).

Figure 3a also plots the series 'net percentage of banks increasing spreads of loan rates over cost of funds', from the FRB Senior Loan Officer Opinion Survey on Bank Lending Practices, SLOOS. (The series represents the percentage of banks increasing spreads minus the percentage of banks lowering spreads; the plotted series is scaled so that its standard deviation equals that of the baseline loan spread.) That series is 
positively correlated with the baseline loan spread (correlation 0.39 for 1990-2010), and negatively correlated with the bank capital ratio $(-0.47$ for $1990-2007$; -0.21 for 1990 2010).

Figure 3b plots Gilchrist and Zakrajšek's (2011a) excess US commercial bond premium, constructed by subtracting expected bond default probabilities from the spread between the yield on US commercial bonds and the yield on US Treasury bonds. ${ }^{14}$ As commercial banks are key players in the commercial bond market, the commercial bond premium might be informative about credit spreads/market conditions. ${ }^{15}$ The excess bond premium too is negatively correlated with the bank capital ratio (correlation: -0.49 for $1990-2007$; -0.15 for 1990-2010). The bond premium is positively correlated with the baseline loan rate spread (0.29) and with the SLOOS 'net percentage of banks increasing spreads' (0.79).

Overall, the data are thus consistent with the model's prediction that the spread is inversely related to the bank capital ratio (see (7)). The absence of an pronounced inverse relation during the crisis might be due to the fact that the measured bank capital ratio overstates the true capital ratio during the crisis (see discussion above), or that the required bank capital ratio rose during the crisis (this could rationalize the observed increase in the loan rate spread, during the crisis, without a fall in the bank capital ratio).

Table 2 reports moments of Hodrick-Prescott (HP) filtered macro and banking variables, for the US and the EA (1990-2010). GDP volatility is very similar in the US $(1.12 \%)$ and the EA (1.14\%). Consumption is less volatile than GDP, while investment is markedly more volatile than GDP. US investment is almost twice as volatile as EA investment. In both 'countries', loans are more volatile than output, while the loan spread is countercyclical. Real activity and loans are positively correlated across the US and EA.

\footnotetext{
${ }^{14}$ I thank Egon Zakrajšek for providing me with the excess bond premium series, and with the business loan and loan capacity data used below.

${ }^{15}$ Gilchrist and Zakrajšek (2011a) argue that 'an increase in the excess bond premium reflects [...] a contraction of the supply of credit with significant adverse consequences for the macroeconomy' (p.31).
} 


\section{Estimation results}

\subsection{Posterior parameter estimates (Table 3 )}

Columns (4)-(6) of Table 3 respectively report the means, the modes and the standard deviations of the posterior parameter distribution, for the baseline model (posterior means and modes are very close); Cols. (7) and (8) show the 5th and 95th percentiles of the posterior parameter distributions. ${ }^{16}$

The data are informative about the estimated parameters: in almost all cases, the posterior parameter distributions have lower standard deviations than the prior distributions; the posterior means often differ noticeably from the prior means. The posterior estimate (mode) of $4 \gamma \phi^{\prime \prime}$ indicates that a 1 percentage increase in the bank capital ratio leads to a 44 basis point reduction in the annualized loan rate spread, and that a 1 percentage point rise in the required bank capital ratio $\left(\gamma_{t}\right)$ increases the loan rate spread by 45 basis points p.a..

The posterior estimates also show that EA loan loss shocks are more volatile than

US loan loss shocks- the posterior modes of the standard deviations of $\varepsilon_{t}^{\Delta}$ and $\varepsilon_{t}^{\Delta *}$ are $0.48 \%$ and $1.38 \%$, respectively. US and EA loan loss shocks are positively correlated (0.34). The required bank capital ratio undergoes sizable fluctuations (posterior mode of std. of $\left.\varepsilon^{\gamma}: 0.53 \%\right)$. The posterior means of the standard deviations of measurement errors are mostly smaller than the prior means. An important exception to this is the sizable standard deviation of measurement error for bank capital ratio (its posterior mode is $1.31 \%){ }^{17}$

\subsection{Business cycle moments implied by posterior estimates (Table 4)}

Table 4 reports model-predicted moments of HP filtered US and EA variables, computed at the posterior mode of the estimated parameters. Column (1) assumes all 11 structural shocks, and measurement error. Cols. (2)-(9) consider moments generated by different subsets of the structural shocks, in isolation, without measurement error. Specifically,

\footnotetext{
${ }^{16}$ The means, standard deviations and deciles of the posterior distributions were generated using the Random Walk Metropolis algorithm (see An and Schorfheide (2007)).

${ }^{17}$ The estimated measurement error for the bank capital ratio is markedly smaller when the model is estimated using data on business loans; see below.
} 
Col. (2) assumes just the 8 non-banking shocks $\varepsilon_{t}^{n b k}$, and Col. (3) assumes just the 3 exogenous banking shocks $\varepsilon_{t}^{b k}$. Cols. (4)-(9) assume just a single type of shock (Col.(4): just TFP shocks; Col. (5): just investment efficiency shocks; etc.). Col. (10) reports empirical moments (from Table 2). ${ }^{18}$

The model with all shocks and measurement error generates predicted statistics that are mostly in the range of the empirical statistics. The predicted standard deviation of US GDP (1.30\%) and of EA GDP (0.88\%) are close to the empirical standard deviations. The model (with all shocks) captures the fact that investment and loans are more volatile than GDP. The model also matches the empirical cross-correlations of most variables with domestic GDP - in particular, it correctly predicts that US and EA loans are procyclical, and that the loan spread is countercyclical. Also, the model correctly predicts that GDP, consumption, investment and loans are positively correlated across the two countries - the predicted cross-country correlation of GDP is 0.44 .

Taken in isolation, TFP shocks and Labour supply shocks induce by far the largest fluctuations in real activity (predicted standard deviation of US and EA GDP with just these shocks: $0.94 \%$ and $0.77 \%$, respectively). The predicted standard deviations of US GDP with just loan loss shocks and with just shocks to the required bank capital ratio are $0.28 \%$ and $0.15 \%$, respectively. With just TFP shocks, just investment efficiency shocks, and just labor supply shocks, GDP is negatively correlated across countries. By contrast, government purchases shocks and the banking shocks induce positive crosscountry output correlations. Notice also that the banking shocks induce a strong negative correlation between the loan rate spread and GDP.

Panel (a1) of Table 7 reports the \% shares of the predicted variances of HP filtered endogenous variables (with measurement error) that are accounted for by the nonbanking shocks $\varepsilon_{t}^{n b k}$ (see rows labeled 'NonBk'), and by the banking shocks $\varepsilon_{t}^{b k}$ (rows

${ }^{18}$ Using (11),(12), the model solution for observables (with measurement error) can be written as: $y_{t}^{\text {obs }}=$ $A(L) \varepsilon_{t-v}^{n b k}+B(L) \varepsilon_{t-v}^{b k}+\mu_{t}$ where $A(L)$ and $B(L)$ are lag polynomials. (The moments in Table 4 pertain to HP filtered series, $y_{t}^{\text {obs,HP}}=H(L) y_{t}^{o b s}$, where $H(L)$ is the HP filter.) By assumption, $\varepsilon_{t}^{n b k}, \varepsilon_{t}^{b k}$ and $\mu_{t}$ are independent at all leads and lags. Thus the predicted variance of endogenous variables under all shocks and measurement error (Col. (1) of Table 4) is the sum of: (i) the variance with just non-banking shocks (Col.(2)); (ii) the variance with just banking shocks (Col. (3)); (ii) the variance of measurement error. By contrast, the variances predicted under the different individual shocks in Cols. (4)-(10) of Table 4 do not add up to the variance with all shocks, as individual shocks are correlated. 
labeled 'Bank'); the remainder represents the contribution of measurement error to the predicted variance. (The variance shares are computed at the posterior mode of the estimated parameters.)

According to the baseline model, the banking shocks account for a $6 \%$ share of US GDP variance, but explain larger shares of the variances of US investment (11.3\% share), employment (15.2\%) and loans (28.1\%). Banking shocks account for roughly 2-5 times larger variance shares of EA variables--GDP: 15.5\%; investment: 55.1\%; employment: $26.5 \%$; loans: $76.3 \%$. Thus, more than half of the variance of EA investment and loans is due to banking shocks. ${ }^{19}$

\subsection{Impulse responses (Table 5)}

Impulse responses (reported in Table 5) help to understand the model's mechanics, and the predicted business cycle moments. The impulse responses are computed at the posterior mode of estimated model parameters. Each impulse response focuses on an isolated innovation, assuming that all other exogenous innovations are zero. ${ }^{20} \mathrm{~A}$ positive innovation to Home TFP raises Home GDP and investment, but leads to a fall in Foreign GDP and investment. The shock raises the income of the Home worker; thus that worker saves more, and her holdings of bank deposits increase--i.e. the bank's debt rises, which lowers the bank capital ratio. This raises the loan rate spread. The deposit rate falls (due to the greater supply of deposits); the Foreign worker responds to this by consuming more, and working less, and hence Foreign GDP falls. Foreign investment falls likewise, as the reduction in Foreign hours worked lowers the marginal product of capital.

Country-specific investment efficiency shocks and labor supply shocks likewise drive Home and Foreign GDP in opposite directions. By contrast, banking shocks induce responses of real activity (and of loans) that are common across the two countries. For example, a rise in the Home loan loss lowers the global bank's capital ratio, which triggers a rise in the loan rate spread; in response to this, loans, investment and GDP fall in both countries. A rise in the required capital ratio $\left(\gamma_{t}\right)$ likewise raises the loan rate

\footnotetext{
${ }^{19}$ Banking shocks account for $85.5 \%$ of the variance of the loan rate spread, but for only $13.7 \%$ of the variance of bank capital, which reflects the sizable estimated measurement error in that variable.

${ }^{20}$ To save space, Table 5 does not show responses to EA 'non-banking' shocks- those responses are qualitatively similar to the responses to US 'non-banking' shocks (reported in Table).
} 
spread (see (7)); on impact, this too lowers loans, investment and real activity in both countries. Note also that banking shocks drive the loan spread and output in opposite directions. According to the baseline estimates, an unanticipated US loan loss of $1 \$$ lowers both US and EA GDP by about 0.15 \$, on impact. An unanticipated increase in the required bank ratio by one percentage point lowers US and EA GDP by $0.21 \%$, on impact.

\subsection{Decomposing historical time series (Figure 4)}

Figure 4 plots the contributions of the banking shocks and of US and EA non-banking shocks to the historical time series (the decomposition is computed at the posterior mode of the estimated parameters). ${ }^{21}$ Thick continuous lines show the historical data; the thin continuous lines indicate the contribution of banking shocks, while the dashed-dotted and dashed lines represent the contributions of US and EA non-banking shocks, respectively.

The historical decomposition yields a picture that is consistent with the variance decompositions. Banking shocks matter more for EA GDP than for US GDP. Banking shocks are key drivers of EA investment and employment. During the 2007q4-2009q2 recession, banking shocks account for a $1.6 \%(1.7 \%)$ fall in US (EA) GDP-i.e. the banking shocks capture about $1 / 5$ of the fall in US GDP (-8.5\%) and in EA GDP (-7.5\%), relative to trend. Banking shocks also capture $25 \%$ [30\%] of the fall in US investment [employment], and $60 \%$ [85\%] of the fall in EA investment and employment. Thus, the fall in EA employment can almost fully be accounted for by banking shocks.

In the previous US recession (2001q1-2001q4), banking shocks accounted for 1/4 of the fall in US output and investment, for $1 / 3$ of the fall in EA output and for $2 / 3$ of the fall in EA investment. During the 1990q3-1991q1 US recession, the role of banking shocks was more muted, accounting for 1/10 of the fall in US GDP and investment (the EA did not experience a recession in 1990-91).

Figure 4 shows that the output components accounted for by the domestic nonbanking shocks track historical US and EA GDP very closely. ${ }^{22}$ Foreign non-banking

\footnotetext{
${ }^{21}$ Using smoothed shocks and measurement errors, each historical series can be expressed as the sum of: (i) a 'base' trajectory (dynamic effects of predetermined states in the initial period) plus measurement error; (ii) contributions of each exogenous shock. Figure 4 shows the data and the shock contributions.

${ }^{22}$ This result parallels the finding by de Walque et al. (2005) and Le et al. (2010) that domestic macro shocks are the main drivers of US and EA GDP.
} 
shocks had a stabilizing effect on domestic real activity; eg, during the 2007-09 recession, EA non-banking shocks had a positive influence on US GDP, and thus mitigated the US recession. This reflects the fact that, in the model here, TFP shocks and labor supply shocks are negatively transmitted internationally (see above).

\subsection{Alternative empirical measures of banking variables}

As a robustness check, I estimated the model using other empirical measures of the loan rate spread and of bank loans. Panels (a2)-(a5) of Table 7 report resulting estimates of variance shares explained by banking shocks. These variance shares are higher, by up to a factor of 3, than the baseline shares discussed above (Panel (a1)). ${ }^{23}$ (Posterior parameter estimates obtained from the alternative data sets are in the same range as the baseline estimates, and are thus not reported)

\section{Alternative proxies for the loan rate spread}

In Panels (a2) of Table 7, the baseline loan rate spread is replaced by the series 'net percentage of banks increasing spreads of loan rates over cost of funds' (from SLOOS), while Panel (a3) uses the Gilchrist-Zakrajšek (2011a) excess bond premium series. When the Gilchrist-Zakrajšek excess bond premium is used, 9.2\% (21.8\%) of the variance of US (EA) GDP is due to banking shocks. ${ }^{24}$

\section{Business loans and lending capacity}

In Panel (a4), total bank credit is replaced by US and EA bank loans to the non-financial business sector, while Panel (a5) uses Gilchrist and Zakrajšek's (2011b) measure of US 'business lending capacity' in lieu of US total credit. ${ }^{25}$ Figures $5 \mathrm{a}-\mathrm{b}$ plot these series. Business loans are highly positively correlated with total loans, but more volatile,

\footnotetext{
${ }^{23}$ I also estimated the model using an alternative measure of the bank capital ratio--the capital ratio of US Securities Brokers and Dealers (instead of the capital ratio of US commercial banks). Results are robust to using this measure. Kollmann and Zeugner (2012) analyze the capital ratio dynamics of different subsectors of the finance industry.

${ }^{24}$ Using the SLOOS series 'net percentage of banks tightening lending standards' in lieu of the baseline lending spread yields very similar estimated variance shares.

${ }^{25}$ Gilchrist and Zakrajšek (2011b) point out that, in the US, many business loans are offered under prior commitment (credit lines); hence, business loans respond with a lag to shocks to bank funding. The Gilchrist and Zakrajšek 'business lending capacity' measure is defined as the sum of loans outstanding and of unused commercial bank lending commitments--the authors argue that this variable is more informative (than loans outstanding) for identifying loan supply shifts (no comparable measure exists for the EA).
} 
especially in the US. US lending capacity fell earlier and much more sharply than total lending, during the 2007-09 recession. When these alternative lending (capacity) series are used, then about $10 \%$ of US GDP variance and $25 \%-30 \%$ of EA GDP variance is attributed to the banking shocks. ${ }^{26}$

The following conclusions can be drawn from the robustness analysis in Table 7: Banking shocks matter more for EA macro variables than for US real activity. These shocks account for 5\%-10\% of the unconditional volatility of US GDP, and for $10 \%-25 \%$ of US investment and employment volatility. Banking shocks explain 15\%-30\% of EA GDP volatility, $50 \%-70 \%$ of EA investment volatility and $25 \%-50 \%$ of EA employment volatility. $^{27}$

\subsection{The role of the bank capital requirement}

The presence of an operative bank capital requirement $\phi^{\prime \prime}>0$ is key for the transmission of banking shocks to real activity. Banking shocks have a negligible effect on real activity, but remain important drivers of loans and the bank capital ratio, when $\phi^{\prime \prime}=0$. Columns (9)-(11) of Table 3 reports posterior parameter estimates for a model variant with $\phi^{\prime \prime}=0$ (the priors for parameter other than $\phi^{\prime \prime}$ are the same as in the baseline model). ${ }^{28}$ Table 6 reports the implied predicted business cycle moments, while Panel (b) of Table 7 shows the corresponding variance shares accounted for by non-banking/ banking shocks.

In the absence of an operative bank capital requirement $\left(\phi^{\prime \prime}=0\right)$, the predicted standard deviations of GDP, investment and the loan rate spread generated by banking shocks are negligible $(0.02 \%$ or less); by contrast, non-banking shocks trigger bigger

\footnotetext{
${ }^{26}$ Banking shocks now also account for a much larger share of the variance of the bank capital ratio (above $60 \%$ ); this is due to the fact that the estimated standard deviation of measurement error in the bank capital ratio $(0.4 \%)$ is noticeably smaller than when total credit is used in estimation $(1.3 \%)$.

${ }^{27}$ Nolan and Thoenissen (2009) and Jermann and Quadrini (2012) use closed economy models with collateral-constrained firms (but without banks) to construct estimates of shocks to firms' funding constraints. The authors argue that those shocks can explain up to half of the variance of US GDP. By contrast, the model here assumes that only the bank faces a collateral constraint.

${ }^{28}$ The posterior estimate of the investment technology curvature parameter is basically the same as in the baseline model, but the estimated risk aversion coefficient is slightly lower (0.57). The estimated variability of EA loan losses is again greater than that of US loan losses.
} 
fluctuations of real activity, than in the baseline model (with an operative bank capital requirement). Recall that, in the baseline model, a positive TFP shock leads to an increase in the loan rate spread - the rise in the spread dampens thus the rise in GDP triggered by that shock. When $\phi^{\prime \prime}=0$, the dampening effect of the loan spread response is not present anymore - and real activity responds more strongly to TFP changes (and the other nonbanking shocks). With all simultaneous shocks (and measurement error), the predicted standard deviations of GDP, investment and employment are thus higher than in the baseline model - and higher than the corresponding empirical statistics.

Model fit can be evaluated using the marginal data density, MDD (marginal likelihood). ${ }^{29}$ The log MDD of the baseline model is 3309.78, while the log MDD of the model variant without the operative bank capital constraint is 3156.99 . This implies a Bayes factor (ratio of posterior odds to prior odds) of $e^{152.79}$ that massively favors the baseline model. I also estimated a model variant with an operative bank capital requirement, but without banking shocks; that model has a log MDD of 3141.43, a value markedly below the $\log$ MDD of the baseline model (with banking shocks). ${ }^{30}$ This suggests that both the operative bank capital requirement and the banking shocks help the model to capture the dynamics of the macro and banking variables used in estimation. Importantly, the presence of these model ingredients specifically helps to better explain the 8 US and EA macro variables used in estimation. For these 8 macro variables, the baseline model has a log MDD of 2211.57, while the model variant without an operative bank capital requirement (but with banking shocks) has a log MDD of 2031.49. The model with an operating bank capital requirement, but no banking shocks has a log MDD of 2108.36. Thus, the bank capital requirement and the banking shocks both help explain the macro series better.

\footnotetext{
${ }^{29}$ The MDD measures the out-of-sample predictive ability of the model (Geweke (2001)). The MDDs reported below were computed with the Geweke (1999) harmonic mean estimator, using the parameter draws from the Random Walk Metropolis algorithm (An and Schorfheide (2007))

${ }^{30}$ A model variant without an operative bank capital requirement and without banking shocks has a log MDD of 3118.98 .
} 


\section{Conclusion}

This paper has estimated a two-country model with a global banking system, using US and Euro Area (EA) data (1990-2010), and Bayesian methods. The estimated model matches key US and EA business cycle statistics. Empirically, a model version with an operative bank capital constraint outperforms a structure without such a constraint. A loan loss originating in one country triggers a global output reduction. Banking shocks matter more for EA macro variables than for US real activity. These shocks account for $5 \%-10 \%$ of US GDP volatility, and for $10 \%-25 \%$ of US investment and employment volatility. Banking shocks, explain $15 \%-30 \%$ of EA GDP volatility, 50\%-70\% of EA investment volatility, and $25 \%-50 \%$ of EA employment volatility. During the Great Recession (2007-09), banking shocks accounted for about $20 \%$ of the fall in US and EA GDP, but for more than half of the fall in EA employment and investment. 


\section{DATA APPENDIX}

\section{A.1 Baseline data set used for estimation}

- US GDP, private consumption (total), investment (all at constant prices): from US National Income and Product Accounts (Bureau of Economic Analysis, BEA); the investment series include private and government investment.

- US employment: 'Total nonfarm payrolls: all employees' (Bureau of Labor Statistics)

- US bank loans: outstanding 'total bank credit' by Commercial Bank, deflated using GDP deflator (from June 2011 Flow of Funds, Table L109).

- US bank capital ratio: (total financial assets-total liabilities)/(total financial assets) for Commercial Banks (from June 2011 Flow of Funds, Table L109).

- US loan rate spread: 'Commercial and industrial loan rates spread over intended federal funds rate' ('All loans' series, Survey of Terms of Business Lending, Table E.2, Federal Reserve Board, June 2011).

- EA GDP, private consumption (total), investment (all at constant prices): from ECB Area-Wide Model (AWM) database (10 $0^{\text {th }}$ update, September 2010).

- EA employment: from AWM database.

- EA bank loans: MFI loans to private sector (from ECB monthly bulletin), deflated using the GDP deflator.

\section{A.2 Other variables (used for estimation of model variants)}

- Excess bond premium: spread between the yield on US commercial bonds and the yield on Treasury bonds, minus expected bond default probabilities, as constructed by Gilchrist and Zakrajšek (2011a) using data for a panel of individual bonds.

- 'Net percentage of banks increasing spreads of loan rates over cost of funds': percentage of banks increasing spreads minus the percentage of banks lowering spreads, from the Senior Loan Officer Opinion Survey on Bank Lending Practices, SLOOS (Federal Reserve Board). SLOOS reports a series (net percentages of banks raising spreads) for loans to 'large and middle-market firms' and one for loans to 'small firms'. The two series are very similar (correlation: 0.95). I use the average of the two series.

- US business loans: outstanding commercial bank loans to the non-financial business sector, constructed by Gilchrist and Zakrajšek (2011b).

- EA business loans: MFI loans to non-financial corporations(NFC), from ECB monthly bulletin, deflated using the GDP deflator.

- US business lending capacity: outstanding commercial bank loans plus unused commercial bank lending commitments (credit lines) to the non-financial business sector, constructed by Gilchrist and Zakrajšek (2011b).

\section{A.3 Other variables (used for model calibration)}

- 'Autonomous spending' (G): government purchases plus net exports to third countries (deflated using GDP deflator). Data sources: AWM, BEA and ECB monthly bulletin.

- Investment efficiency: measured as ratio of CPI to Gross Investment Deflator (BEA and AWM).

All series are quarterly and seasonally adjusted (when relevant) 


\section{REFERENCES}

Adolfson, M., S. Laséen, J. Lindé and M. Villani, 2007. Bayesian Estimation of an Open Economy DSGE Model with Incomplete Pass-Through. Journal of International Economics 72, 481-511.

Aikman, D. and M. Paustian, 2006. Bank Capital, Asset Prices and Monetary Policy. Working Paper No. 305, Bank of England.

An, S. and F. Schorfheide, 2007. Bayesian Analysis for DSGE Models. Econometric Reviews 26, 113-172.

Andreasen, M., J. Sondergaard and M. Paustian, 2010. Portfolio Linkages, Financial Shocks and International Business Cycles. Working Paper, Bank of England.

Boivin, J., and M. Giannoni, 2006. DSGE Models in a Data Rich Environment. Working Paper No. 12772, National Bureau of Economic Research.

Coeurdacier, N., R. Kollmann and P. Martin, 2010. International Portfolios, Capital Accumulation and the Dynamics of Capital Flows. Journal of International Economics 80, 100-112.

Correa, R., H. Sapriza and A. Zlate, 2010. International Banks, the Interbank Market, and the Cross-Border Transmission of Business Cycles. Working Paper, International Finance Section, Federal Reserve Board.

Davis, S., 2010. The Adverse Feedback Loop and the Effects of Risk in both the Real and Financial Sectors. Working Paper No. 66, Globalization and Monetary Policy Institute.

de Antonio, D., 2011. What are Shocks Capturing in DSGE Modelling? Noise Versus Structure. Working Paper, National Bank of Belgium.

Devereux, M. and A. Sutherland, 2011. Evaluating International Financial Integration Under Leverage Constraints. European Economic Review 55, 427-442.

Del Negro, M., G. Eggertsson, A. Ferrero, A. and N. Kiyotaki, 2011. The Great Escape?

A Quantitative Evaluation of the Fed's Liquidity Facilities. Staff Report no. 520, Federal Reserve Bank of New York.

de Walque, G, O. Pierrard and A. Rouabah, 2010. Financial (In)Stability, Supervison and Liquidity Injection: A Dynamic General Equilibrium Approach. Economic Journal 120, 1234-1261.

de Walque, G., F. Smets and R. Wouters, 2005. An Estimated Two-Country DSGE Model for the Euro Area and the US Economy. Working Paper, National Bank of Belgium.

Fisher, J., 2006. The Dynamic Effects of Neutral and Investment-Specific Technology Shocks. Journal of Political Economy, Vol 114 No. 3, pp. 413-52.

Freixas, X. and J.-C. Rochet, 2008. The Microeconomics of Banking. MIT Press, Cambridge.

Galí, J., F. Smets and R. Wouters, 2011. Unemployment in an Estimated New Keynesian Model. Working Paper 17084, National Bureau of Economic Research.

Gamber, G. and C. Thoenissen, 2011. Financial Intermediation and the International Business Cycle: the Case of a Small Country with Big Risk. Working Paper, Reserve Bank of New Zealand.

Gertler, M. and N. Kiyotaki, 2011. Financial Intermediation and Credit Policy in Business Cycle Analysis. In: Handbook of Monetary Economics (B. Friedman and M. Woodford, eds.), Vol. 3A, pp.547-599, Elsevier: Amsterdam.

Geweke, J., 1999. Using Simulation Methods for Bayesian Econometric Models: Inference, Development and Communication. Econometric Reviews 18, 1-126. 
-----, 2001. Bayesian Econometrics and Forecasting. Journal of Econometrics 100, 11-15.

Gilchrist, S. and E. Zakrajšek, 2011a. Credit Spreads and Business Cycle Fluctuations. Working Paper No. 17201, National Bureau of Economic Research.

--------, 2011b. Bank Lending and Credit Supply Shocks, Working Paper, Boston University.

Huizinga, H. and L. Laeven, 2009. Accounting Discretion of Banks During a Financial Crisis. Discussion Papers 7381, Centre for Economic Policy Research.

Ireland, P., 2004. A Method for Taking Models to the Data. Journal of Economic Dynamics and Control 28, 1205-1226.

Jacob, P. and G. Peersman, 2011. Dissecting the Dynamics of the US Trade Balance in an Estimated Equilibrium Model. Working Paper, Ghent University.

Jermann, U. and V. Quadrini, 2012. Macroeconomic Effects of Financial Shocks, American Economic Review 102, 238-271.

Justiniano, A, and B. Preston, 2010. Can Structural Small Open Economy Models Account for the Influence of Foreign Disturbances? Journal of International Economics 81, 61-74.

Justiniano, A, G. Primiceri and A. Tambalotti, 2008. Investment Shocks and Business Cycles. Journal of Monetary Economics 57, 132-145.

Kollmann, R., 1991. Essays on International Business Cycles. PhD Dissertation, University of Chicago.

Kollmann, R., Z. Enders and G. Müller, 2011. Global Banking and International Business Cycles. European Economic Review 55, 407-426.

Kollmann, R. and S. Zeugner, 2012. Leverage as a Predictor of Real Activity and Volatility. Forthcoming in: Journal or Economic Dynamics and Control.

Kollmann, R., W. Roeger and J. in't Veld, 2012a. Fiscal Policy in a Financial Crisis: Standard Policy versus Bank Rescue Measures. American Economic Review (Papers and Proceedings) 102, 1-7.

Kollmann, R., M. Ratto, W. Roeger and J. in't Veld, 2012b. Banks, Fiscal Policy and the Financial Crisis. Working Paper, ECARES, Université Libre de Bruxelles.

Le, V., D. Meenagh, P. Minford and M. Wickens, 2010. Two Orthogonal Continents? Testing a Two-Country DSGE Model of the US and the EU Using Direct Inference. Open Economies Review 21, 23-44.

Nguyen, H., 2011. International Crisis Transmission and Asymmetric Recoveries. Working Paper, World Bank.

Nolan, C. and C. Thoenissen, 2009. Financial Shocks and the US Business Cycle. Journal of Monetary Economics 56, 596-604.

Perri, F. and V. Quadrini, 2011. International Recessions. Working Paper, University of Minnesota.

Rabanal, P. and V. Tuesta, 2006. Euro-Dollar Real Exchange Rate Dynamics in an Estimated Two-Country Model: What is Important and What is Not? Working Paper 06/177, International Monetary Fund.

Schmitt-Grohé, S. and M. Uribe, 2003. Closing Small Open Economy Models. Journal of International Economics 61, 163-185.

Smets, F. and R. Wouters, 2007. Shocks and Frictions in US Business Cycles: A Bayesian DSGE Approach. American Economic Review 97, 586-660. 
Ueda, K., 2010. Banking Globalization and International Business Cycles. Working Paper, Institute for Monetary and Economic Studies, Bank of Japan.

Van den Heuvel, S., 2008. The Welfare Cost of Bank Capital Requirements. Journal of Monetary Economics 55, 298-320.

Van Wincoop, E., 2011. International Contagion Through Leveraged Financial Institutions. Working Paper, University of Virginia. 
Table 1. Time series properties of non-bank forcing variables (1990q1-2010q3)

(a) Standard deviations (in \%, diagonal) and cross-correlations (off-diagonal elements)

\begin{tabular}{|c|c|c|c|c|c|c|c|c|}
\hline & US TFP & EA TFP & US Ieff & EA Ieff & US G & EA G & US LS & EA LS \\
\hline US TFP & 1.34 & 0.51 & 0.27 & 0.20 & -0.71 & -0.24 & -0.53 & -0.36 \\
\hline EA TFP & & 1.68 & 0.53 & 0.63 & -0.75 & 0.41 & -0.88 & 0.23 \\
\hline US Ieff & & & 2.76 & 0.84 & -0.12 & 0.16 & -0.48 & 0.28 \\
\hline EA Ieff & & & & 1.74 & -0.27 & 0.37 & -0.57 & 0.58 \\
\hline US G & & & & & 6.58 & -0.13 & 0.73 & 0.02 \\
\hline EA G & & & & & & 2.49 & -0.17 & 0.71 \\
\hline US LS & & & & & & & 3.12 & -0.02 \\
\hline EA LS & & & & & & & & 1.83 \\
\hline \multicolumn{9}{|c|}{ (b) Autocorrelations } \\
\hline & US TFP & EA TFP & US Ieff & EA Ieff & US G & EA G & US LS & EA LS \\
\hline & 0.93 & 0.96 & 0.97 & 0.98 & 0.92 & 0.81 & 0.96 & 0.93 \\
\hline \multicolumn{9}{|c|}{ (c) Standard deviations of innovations (in \%) } \\
\hline & US TFP & EA TFP & US Ieff & EA Ieff & US G & EA G & US LS & EA LS \\
\hline & 0.48 & 0.48 & 0.64 & 0.31 & 2.61 & 1.43 & 0.61 & 0.48 \\
\hline
\end{tabular}

Note: The Table reports sample moments of empirical measures of US and Euro Area (EA) 'nonbanking' forcing variables (in linearly detrended log form). Panel (a) reports \% standard deviations (on main diagonal), and cross-correlations (off-diagonal elements). Panel (b) reports first-order autocorrelations. Panel (c) reports \% standard deviations of residuals of univariate AR(1) equations fitted to each variable.

TFP: total factor productivity $(\theta)$; Ieff: investment efficiency $(\Xi)$; G: autonomous spending (government consumption plus net exports to third countries); LS: Labor supply shock $\left(\Psi^{N}\right)$.

Log TFP is estimated as $\ln \left(Y_{t}\right)-0.7 \ln \left(N_{t}\right)$ where $Y_{t}$ and $N_{t}$ are GDP and employment, respectively. The estimate of investment efficiency is the ratio of the CPI to the investment deflator. The estimate of the $\log$ labor supply shock is $\ln \left(Y_{t}\right)-\ln \left(N_{t}\right)-\ln \left(C_{t}\right)$, where $C_{t}$ is private consumption. 


\begin{tabular}{|c|c|c|}
\hline & US & EA \\
\hline \multicolumn{3}{|c|}{ Standard deviations (in\%) } \\
\hline GDP (Y) & 1.12 & 1.14 \\
\hline Consumption & 0.92 & 0.78 \\
\hline Investment & 5.10 & 2.89 \\
\hline Employment & 1.16 & 0.71 \\
\hline Loans & 1.61 & 1.98 \\
\hline Bank capital ratio & 0.49 & -- \\
\hline Loan rate spread (p.a.) & 0.19 & 0.38 \\
\hline \multicolumn{3}{|c|}{ Correlations with domestic GDP } \\
\hline Consumption & 0.89 & 0.83 \\
\hline Investment & 0.92 & 0.93 \\
\hline Employment & 0.79 & 0.83 \\
\hline Loans & 0.48 & 0.59 \\
\hline Bank capital ratio & 0.19 & -0.01 \\
\hline Loan rate spread & -0.52 & -0.91 \\
\hline \multicolumn{3}{|c|}{ Cross-country correlations } \\
\hline GDP & & 0.56 \\
\hline Consumption & & 0.39 \\
\hline Investment & & 0.45 \\
\hline Employment & & 0.53 \\
\hline Loans & & 0.53 \\
\hline Loan rate spread & & 0.79 \\
\hline
\end{tabular}

Note: Moments of HP filtered series are shown (GDP, consumption, investment, employment and loans were logged before applying the filter). The bank capital ratio is expressed in fractional units. The loan rate spread is expressed in fractional units per annum. The correlations of the bank capital ratio with domestic GDP reported in the Table are correlations of the US commercial bank capital ratio with US GDP and EA GDP. Sample period: 1990q1-2010q3 (except for EA loan spread: 2003q1-2010q3). 
Table 3. Prior and posterior parameter distributions for the baseline model $\left(\phi^{\prime \prime}>0\right)$ and a model variant without operative bank capital requirement $\left(\phi^{\prime \prime}=0\right)$

\begin{tabular}{|c|c|c|c|c|c|c|c|c|c|c|c|}
\hline Parameter & \multicolumn{3}{|c|}{ Prior distribution } & \multicolumn{5}{|c|}{$\begin{array}{c}\text { Baseline model: } \\
\text { Posterior distribution }\end{array}$} & \multicolumn{3}{|c|}{$\begin{array}{l}\text { Model with } \phi^{\prime \prime}=0 \text { : } \\
\text { Posterior distribution }\end{array}$} \\
\hline & (1) & (2) & (3) & (4) & (5) & (6) & (7) & (8) & (9) & $(10)$ & (11) \\
\hline \multicolumn{12}{|c|}{ Behavioral parameters } \\
\hline $4 \gamma \phi^{\prime \prime}$ & 0.20 & 0.10 & G & 0.44 & 0.44 & 0.06 & 0.34 & 0.54 & 0.00 & 0.00 & 0.00 \\
\hline$\xi "$ & 1.00 & 0.50 & G & 0.09 & 0.09 & 0.01 & 0.07 & 0.11 & 0.08 & 0.08 & 0.01 \\
\hline$\sigma$ & 1.00 & 0.50 & G & 0.81 & 0.81 & 0.05 & 0.72 & 0.90 & 0.57 & 0.58 & 0.04 \\
\hline \multicolumn{12}{|c|}{ Parameters of banking shocks distributions } \\
\hline $\operatorname{Std}\left(\varepsilon^{\Delta}\right)$ & 0.50 & 0.10 & IG & 0.48 & 0.51 & 0.07 & 0.39 & 0.64 & 0.57 & 0.62 & 0.10 \\
\hline $\operatorname{Std}\left(\varepsilon^{\Delta^{*}}\right)$ & 0.50 & 0.10 & IG & 1.38 & 1.41 & 0.17 & 1.15 & 1.71 & 0.67 & 0.71 & 0.09 \\
\hline $\operatorname{Std}\left(\varepsilon^{\gamma}\right)$ & 0.50 & 0.10 & IG & 0.53 & 0.56 & 0.07 & 0.45 & 0.70 & 0.46 & 0.50 & 0.10 \\
\hline $\operatorname{Corr}\left(\varepsilon^{\Delta}, \varepsilon^{\Delta^{*}}\right)$ & 0.50 & 0.10 & $\mathrm{~B}$ & 0.34 & 0.35 & 0.08 & 0.23 & 0.49 & 0.46 & 0.45 & 0.08 \\
\hline$\rho^{\Delta}$ & 0.50 & 0.10 & B & 0.59 & 0.56 & 0.07 & 0.44 & 0.67 & 0.54 & 0.52 & 0.07 \\
\hline$\rho^{\Delta^{*}}$ & 0.50 & 0.10 & B & 0.48 & 0.48 & 0.06 & 0.38 & 0.59 & 0.91 & 0.90 & 0.02 \\
\hline$\rho^{\gamma}$ & 0.50 & 0.10 & B & 0.79 & 0.78 & 0.03 & 0.72 & 0.83 & 0.56 & 0.59 & 0.14 \\
\hline$\vartheta^{\Delta}$ & 0.00 & 0.10 & $\mathrm{~N}$ & 0.10 & 0.11 & 0.02 & 0.07 & 0.15 & 0.14 & 0.14 & 0.02 \\
\hline$\vartheta^{\gamma}$ & 0.00 & 0.10 & $\mathrm{~N}$ & 0.07 & 0.06 & 0.02 & 0.03 & 0.10 & 0.13 & 0.16 & 0.12 \\
\hline \multicolumn{12}{|c|}{ Standard deviations (\%) of measurement errors } \\
\hline GDP US & 0.79 & 0.16 & IG & 0.40 & 0.40 & 0.04 & 0.34 & 0.48 & 0.41 & 0.41 & 0.05 \\
\hline GDP EA & 0.54 & 0.11 & IG & 0.30 & 0.30 & 0.04 & 0.25 & 0.37 & 0.38 & 0.39 & 0.05 \\
\hline C US & 0.78 & 0.16 & IG & 0.57 & 0.58 & 0.06 & 0.47 & 0.69 & 0.43 & 0.44 & 0.05 \\
\hline C EA & 0.44 & 0.09 & IG & 0.37 & 0.38 & 0.05 & 0.29 & 0.48 & 0.31 & 0.33 & 0.05 \\
\hline I US & 3.15 & 0.63 & IG & 3.46 & 3.50 & 0.35 & 2.95 & 4.11 & 4.05 & 4.07 & 0.36 \\
\hline I EA & 1.33 & 0.26 & IG & 0.95 & 1.01 & 0.15 & 0.78 & 1.29 & 1.76 & 1.77 & 0.35 \\
\hline $\mathrm{N}$ US & 0.47 & 0.09 & IG & 0.45 & 0.46 & 0.05 & 0.37 & 0.56 & 0.47 & 0.48 & 0.06 \\
\hline N EA & 0.45 & 0.09 & IG & 0.28 & 0.29 & 0.03 & 0.23 & 0.35 & 0.31 & 0.31 & 0.04 \\
\hline Loans US & 0.85 & 0.17 & IG & 0.87 & 0.88 & 0.07 & 0.76 & 1.01 & 0.86 & 0.88 & 0.09 \\
\hline Loans EA & 1.10 & 0.22 & IG & 0.47 & 0.48 & 0.05 & 0.40 & 0.58 & 0.45 & 0.46 & 0.05 \\
\hline Bank cap. ratio & 0.21 & 0.04 & IG & 1.31 & 1.32 & 0.13 & 1.12 & 1.54 & 0.88 & 0.88 & 0.15 \\
\hline Loan rate spread & 0.03 & 0.01 & IG & 0.02 & 0.02 & 0.00 & 0.02 & 0.03 & 0.10 & 0.10 & 0.01 \\
\hline
\end{tabular}

Notes: Cols. (1) and (2) shows the means and standard deviations of the prior distribution for model parameters. Col. (3) indicates the distribution function of the prior (B: Beta; G: Gamma; IG: Inverted Gamma; N: Normal). Cols. (4)-(8) show statistics of the posterior parameter distribution, for the baseline model (means, modes, standard deviations, $5^{\text {th }}$ and $95^{\text {th }}$ percentiles). Cols. (9)-(11) show statistics of the posterior parameter distribution for a model variant without an operative bank capital requirement (for that variant, the priors in Cols. (1)-(3) are used, except that $\phi^{\prime \prime}$ is set at $\phi^{\prime \prime}=0$ ). Posterior distributions are computed using the Random Walk Metropolis algorithm (250,000 draws of which the first 50,000 were discarded) 
Non-

All banking Banking Invest. shocks shocks shocks TFP $\quad$ Eff. G LabS Loss Bnk.Cap Data

(1) (2)

(3)

(4)

(5)

(6)

(7)

(8)

(9)

(10)

(a) Country 'Home' (US) moments

Standard deviations (in \%)

$\begin{array}{lcrrrrrrrrr}\text { GDP }(Y) & 1.30 & 1.20 & 0.32 & 0.94 & 0.14 & 0.23 & 0.78 & 0.28 & 0.15 & 1.12 \\ \text { Consumption } & 1.34 & 1.21 & 0.14 & 0.64 & 0.10 & 0.10 & 0.63 & 0.12 & 0.06 & 0.92 \\ \text { Investment } & 5.37 & 3.80 & 1.81 & 1.54 & 2.33 & 0.41 & 1.58 & 1.60 & 0.84 & 5.10 \\ \text { Employment } & 1.16 & 0.97 & 0.45 & 0.49 & 0.12 & 0.33 & 1.09 & 0.40 & 0.21 & 1.16 \\ \text { Loans } & 1.49 & 0.95 & 0.79 & 0.44 & 0.92 & 0.17 & 0.34 & 0.77 & 0.16 & 1.61 \\ \text { Bank cap ratio } & 1.36 & 0.10 & 0.50 & 0.07 & 0.03 & 0.01 & 0.04 & 0.47 & 0.19 & 0.49 \\ \text { Loan spread } & 0.38 & 0.12 & 0.36 & 0.08 & 0.03 & 0.02 & 0.05 & 0.19 & 0.29 & 0.19 \\ \text { Correlations with domestic GDP } & & & & & & & & & & \\ \text { Consumption } & 0.76 & 0.93 & -0.87 & 0.93 & 0.26 & -0.98 & 0.91 & -0.85 & -0.92 & 0.89 \\ \text { Investment } & 0.61 & 0.81 & 0.99 & 0.93 & -0.03 & 0.12 & 0.95 & 0.99 & 0.99 & 0.92 \\ \text { Employment } & 0.79 & 0.89 & 0.99 & 0.90 & 0.85 & 0.99 & 0.99 & 0.99 & 0.99 & 0.79 \\ \text { Loans } & 0.33 & 0.45 & 0.47 & 0.46 & 0.80 & 0.24 & 0.69 & 0.46 & 0.71 & 0.48 \\ \text { Bank cap ratio } & 0.04 & -0.49 & 0.84 & -0.33 & -0.63 & -0.36 & -0.11 & 0.93 & 0.47 & 0.19 \\ \text { Loan spread } & -0.02 & 0.58 & -0.82 & 0.42 & 0.62 & 0.65 & 0.29 & -0.94 & -0.91 & -0.52\end{array}$

(b) Country 'Foreign' (EA) moments

Standard deviations (in\%)

$\begin{array}{lcrrrrrrrrr}\text { GDP (Y) } & 0.88 & 0.75 & 0.35 & 0.77 & 0.29 & 0.14 & 0.74 & 0.31 & 0.15 & 1.14 \\ \text { Consumption } & 0.91 & 0.82 & 0.16 & 0.74 & 0.20 & 0.08 & 0.42 & 0.15 & 0.06 & 0.78 \\ \text { Investment } & 2.52 & 1.41 & 1.87 & 1.57 & 0.71 & 0.56 & 1.56 & 1.67 & 0.84 & 2.89 \\ \text { Employment } & 0.95 & 0.77 & 0.49 & 0.43 & 0.42 & 0.20 & 1.03 & 0.44 & 0.21 & 0.71 \\ \text { Loans } & 1.14 & 0.32 & 1.00 & 0.14 & 0.24 & 0.15 & 0.19 & 0.99 & 0.12 & 1.98 \\ \text { Bank cap ratio } & 1.36 & 0.10 & 0.50 & 0.07 & 0.03 & 0.01 & 0.04 & 0.47 & 0.19 & -- \\ \text { Loan spread } & 0.38 & 0.12 & 0.36 & 0.08 & 0.03 & 0.02 & 0.05 & 0.19 & 0.29 & 0.38 \\ \text { Correlations with domestic GDP } & & & & & & & & \\ \text { Consumption } & 0.46 & 0.68 & -0.92 & 0.85 & -0.96 & -0.89 & 0.92 & -0.93 & -0.92 & 0.83 \\ \text { Investment } & 0.54 & 0.52 & 0.99 & 0.96 & -0.50 & -0.47 & 0.91 & 0.99 & 0.99 & 0.93 \\ \text { Employment } & 0.59 & 0.56 & 0.99 & 0.59 & 0.99 & 0.99 & 0.99 & 0.99 & 0.99 & 0.83 \\ \text { Loans } & 0.27 & 0.19 & 0.65 & 0.72 & 0.02 & 0.14 & 0.56 & 0.69 & 0.80 & 0.62 \\ \text { Bank cap ratio } & 0.27 & -0.33 & 0.86 & -0.34 & -0.28 & -0.00 & -0.36 & 0.94 & 0.49 & -0.01 \\ \text { Loan spread } & -0.18 & 0.42 & -0.81 & 0.40 & 0.34 & 0.29 & 0.30 & -0.95 & -0.90 & -0.91 \\ \text { (c) Cross-coundry } & & & & & & & & & & \\ \text { GDP } & 0.44 & 0.44 & 0.99 & -0.06 & -0.26 & 0.43 & -0.53 & 0.99 & 0.99 & 0.56 \\ \text { Consumption } & 0.76 & 0.91 & 0.94 & 0.70 & 0.72 & 0.80 & 0.18 & 0.93 & 0.99 & 0.39 \\ \text { Investment } & 0.30 & 0.15 & 0.99 & -0.20 & -0.58 & -0.16 & -0.72 & 0.99 & 0.99 & 0.45 \\ \text { Employment } & -0.01 & -0.31 & 0.99 & -0.91 & -0.04 & 0.47 & -0.52 & 0.99 & 0.99 & 0.53 \\ \text { Loans } & 0.17 & -0.73 & 0.65 & -0.56 & -0.83 & 0.25 & -0.72 & 0.65 & 0.95 & 0.64 \\ \text { Loan spread } & 1.00 & 1.00 & 1.00 & 1.00 & 1.00 & 1.00 & 1.00 & 1.00 & 1.00 & 0.79\end{array}$

Note: The Table shows moments of HP filtered model variables, computed at the posterior mode of the estimated parameters. The bank capital ratio is expressed in factional units. The loan rate spread is expressed in fractional units per annum. Other variables are normalized by steady state values. Col. (1) assumes all 11 structural shocks and measurement error. In Cols. (2)-(9), subsets of shocks are assumed in isolation, without measurement error (model not re-estimated). Col. (2): just the 'non-banking' shocks, $\varepsilon_{t}^{n b k}$; Col. (3): just banking shocks, $\varepsilon_{t}^{b k}$. Col. (4): just Home and Foreign TFP shocks; Col. (5): just shocks to investment efficiency; Col. (6): just shocks to government purchases; Col.(7): just labor supply shocks; Col.(8): just loan loss shocks; Col. (9): just shock to required bank capital ratio $\left(\gamma_{t}\right)$. Col. (10) shows empirical moments (from Table 2). 


\begin{tabular}{|c|c|c|c|c|c|c|c|c|}
\hline Horizon & 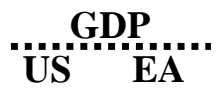 & 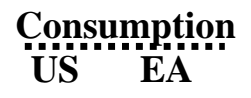 & $\begin{array}{l}\text { Investment. } \\
\text { US }{ }_{\text {EA }}\end{array}$ & $\begin{array}{l}\text { Employment } \\
\text { US }{ }_{\text {EA }}\end{array}$ & "...ي日 & EA & $\begin{array}{c}\text { Bank Cap. } \\
\text { Ratio }\end{array}$ & $\begin{array}{l}\text { Loan } \\
\text { Sprea }\end{array}$ \\
\hline & (1) (2) & (3) (4) & (5) & (7) & (9) & (10) & (11) & (12) \\
\hline \multicolumn{9}{|c|}{ (a) Home country TFP shock (1\%) } \\
\hline 0 & $1.63-0.48$ & $0.92 \quad 0.18$ & $2.84-0.80$ & $0.88-0.68$ & 0.03 & 0.00 & -1.51 & 2.60 \\
\hline 4 & $1.15-0.40$ & $0.85 \quad 0.11$ & $1.20-0.52$ & $0.48-0.54$ & -0.41 & 0.06 & -7.54 & 8.46 \\
\hline 20 & $0.56-0.15$ & $0.62-0.01$ & $-0.04 \quad 0.12$ & $0.08-0.18$ & -1.63 & 0.34 & -7.98 & 7.85 \\
\hline
\end{tabular}

(b) Home investment efficiency shock (1\%)

\begin{tabular}{|c|c|c|c|c|c|c|c|}
\hline 0 & $-0.12 \quad 0.41$ & $0.01-0.24$ & $3.33-1.51$ & $\begin{array}{ll}-0.18 & 0.57\end{array}$ & $0.36-0.15$ & -0.74 & 0.86 \\
\hline 4 & $0.08 \quad 0.13$ & $0.09-0.17$ & $2.41-1.27$ & $\begin{array}{ll}-0.03 & 0.25\end{array}$ & $1.61-0.58$ & -2.52 & 2.56 \\
\hline 20 & $0.33-0.20$ & $0.24-0.08$ & $0.39-0.31$ & $0.12-0.15$ & $2.94-1.02$ & -2.28 & 2.2 \\
\hline
\end{tabular}

(c) Home government purchases shock (1\%)

$\begin{array}{lllllllllllll}0 & 0.06 & 0.02 & -0.03 & -0.01 & 0.03 & -0.15 & 0.09 & 0.03 & -0.00 & -0.01 & -0.00 & 0.15 \\ 4 & 0.06 & -0.00 & -0.02 & -0.01 & 0.03 & -0.12 & 0.08 & 0.00 & -0.02 & -0.05 & -0.18 & 0.47 \\ 20 & 0.04 & -0.02 & -0.01 & -0.01 & 0.01 & -0.01 & 0.05 & -0.01 & -0.10 & -0.06 & -0.17 & 0.28\end{array}$

(d) Home labor supply shock (1\%)

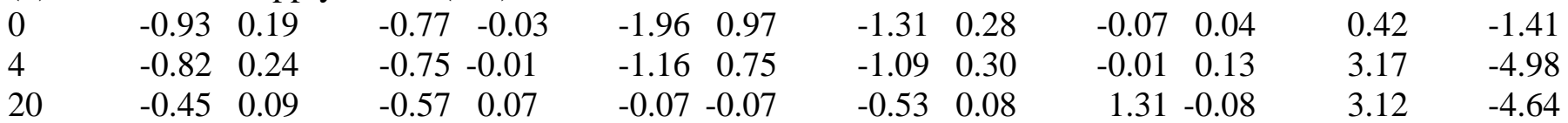

(e) Home loan loss shock (1\% of steady state GDP)

\begin{tabular}{|c|c|c|c|c|c|c|c|}
\hline 0 & $-0.14-0.16$ & $0.08 \quad 0.04$ & $-0.83-0.87$ & $-0.20-0.23$ & $-0.52-0.04$ & -14.37 & 6.26 \\
\hline 4 & $-0.09-0.11$ & $0.03-0.01$ & $-0.47-0.48$ & $-0.10-0.13$ & $-1.23-0.11$ & -21.22 & 8.63 \\
\hline 20 & $0.01-0.00$ & $-0.00-0.05$ & $0.06 \quad 0.08$ & $0.03 \quad 0.02$ & $-1.23-0.02$ & -3.28 & 1.37 \\
\hline
\end{tabular}

(f) Foreign loan loss shock (1\% of steady state GDP)

\begin{tabular}{|c|c|c|c|c|c|c|c|}
\hline 0 & $-0.12-0.13$ & $0.04 \quad 0.07$ & $-0.70-0.73$ & $-0.17-0.19$ & $-0.05-0.31$ & -14.62 & 6.46 \\
\hline 4 & $-0.07-0.08$ & $\begin{array}{ll}-0.01 & 0.03\end{array}$ & $-0.36-0.37$ & $-0.08-0.10$ & $-0.15-0.61$ & -17.31 & 7.06 \\
\hline ח & $0.00 \quad 0.00$ & $-0.03-0.00$ & $0.05 \quad 0.06$ & $0.02 \quad 0.02$ & $-0.09-0.54$ & -2.45 & 1.03 \\
\hline
\end{tabular}

(g) Shock to required bank capital ratio (1 percentage point)

\begin{tabular}{|c|c|c|c|c|c|c|c|}
\hline 0 & $-0.21-0.21$ & $0.08 \quad 0.08$ & $-1.17-1.14$ & $-0.2 \mathrm{C}$ & -0.28 & -0.09 & -0.0 \\
\hline 4 & $0.05 \quad 0.06$ & $-0.03-0.04$ & $0.33 \quad 0.36$ & $0.0 \varsigma$ & 0.10 & $0.0 €$ & 0.0 \\
\hline 20 & $\begin{array}{ll}0.02 & 0.03\end{array}$ & $0.02 \quad 0.02$ & 0.07 & 0.01 & 0.02 & 0.33 & 0.2 \\
\hline
\end{tabular}

Note: The Table shows dynamic responses to exogenous shocks, after 0, 4 and 20 quarters (see left-most column labeled 'Horizon'), of the variables listed at the top of the Table. The responses are computed at the posterior mode of the estimated parameters. In each case, an isolated innovation is considered, assuming that all other exogenous innovations are zero. Panel (a): 1\% innovation to Home TFP $(\theta)$; Panel (b): 1\% innovation to US investment efficiency ( $\Xi$ ); Panel (c): 1\% innovation to government purchases $(G)$; Panel (d): $1 \%$ innovation to US labor supply preference parameter ( $\Psi^{N}$ ); Panel (e): innovation to Home loan loss $(\Delta)$ worth $1 \%$ of steady state GDP; Panel (f) innovation to Foreign loan loss ( $\Delta^{*}$ ) worth $1 \%$ of steady state GDP; Panel (g) innovation that raises required bank capital ratio $(\gamma)$ by 1 percentage point. Cols. (1)-(2): Responses of US and EA GDP; Cols. (3)-(4): US and EA consumption; Cols. (5)-(6): US and EA investment; Cols. (7)-(8): US and EA employment; Cols. (9)-(10): US and EA loans; Col. (11): bank capital ratio; Col. (12): Loan rate spread. Responses of the bank capital ratio are in basis points. Responses of the loan spread are in bp per annum. Other responses are in percentage points of steady state values. 
Non-

$\begin{array}{cccccccc}\text { All } & \begin{array}{c}\text { banking } \\ \text { shocks }\end{array} & \begin{array}{c}\text { Banking } \\ \text { shocks }\end{array} & \text { TFP } & \begin{array}{c}\text { Invest. } \\ \text { Eff. }\end{array} \quad \text { G } & \text { LabS } & \begin{array}{c}\text { Loan } \\ \text { Loss }\end{array} & \text { Bnk.Cap }\end{array}$ Data

(1) (2)

(3)

(4)

(5)

(6)

(7)

$(8)$

(9)

(10)

(a) Country 'Home' (US) moments

Standard deviations (in\%)

GDP (Y)

Consumption

1.83

Investment

1.27

1.79

1.20

0.01

6.43

0.06

1.25

0.21

0.02

1.77

0.00

1.43

0.60

Loans

1.83

Bank cap ratio

1.12

0.52

0.52

0.00

0.01

0.62

2.79

0.87

0.43

0.39

0.00

0.23

3.12

0.22

1.19

0.16

0.00

0.19

0.83

0.80

$-0.20$

0.25

$-0.83$

$0.95 \quad-0.12$

$0.98 \quad 0.39$

0.23

0.99

0.00

0.00

1.12

0.15

0.76

0.06

0.00

0.92

0.44

2.66

0.00

0.02

5.10

0.33

1.39

0.00

0.00

1.16

0.16

0.52

0.60

0.00

1.61

0.08

0.32

0.52

0.00

0.49

0.19

Correlations with domestic GDP

Investment

0.75

0.96

0.99

0.90

$-0.95$

0.99

0.35

$-0.65$

0.89

$0.68 \quad 0.85$

0.49

0.95

0.10

0.99

0.92

Loans

0.41

Loan spread

0.01

0.87

$0.21-0.28$

0.34

0.99

0.07

0.98

0.79

$0.74 \quad 0.70$

0.15

0.72

$-0.37$

0.75

0.48

$-0.11$

0.45

0.78

0.19

0.88

0.67

$-0.45$

$-0.99$

$-0.52$

(b) Country 'Foreign' (EA) moments

Standard deviations (in\%)

$\begin{array}{lll}\text { GDP }(Y) & 1.31 & 1.25 \\ \text { Consumption } & 1.10 & 1.06 \\ \text { Investment } & 3.75 & 3.34 \\ \text { Employment } & 1.20 & 1.17 \\ \text { Loans } & 1.35 & 1.04 \\ \text { Bank cap ratio } & 1.12 & 0.52 \\ \text { Loan spread } & 0.38 & 0.00\end{array}$

Correlations with domestic GDP

$\begin{array}{llr}\text { Consumption } & 0.71 & 0.77 \\ \text { Investment } & 0.76 & 0.89 \\ \text { Employment } & 0.83 & 0.89 \\ \text { Loans } & 0.43 & 0.59 \\ \text { Bank cap ratio } & 0.35 & 0.51 \\ \text { Loan spread } & 0.47 & 0.83 \\ \text { (c) Cross-country correlations }\end{array}$

$\begin{array}{lll}\text { GDP } & 0.70 & 0.75\end{array}$

$\begin{array}{lll}\text { Consumption } \quad 0.78 & 0.86\end{array}$

Investment $\quad 0.58 \quad 0.77$

Employment $\quad 0.49$

Loans $\quad 0.23$

Loan spread $\quad 1.00$

0.53

0.01

$1.09 \quad 0.39$

0.16

0.89

0.00

0.01

1.14

$1.04 \quad 0.33$

0.12

0.59

0.07

0.00

0.78

0.02

$3.06 \quad 0.82$

0.32

2.12

0.00

0.02

2.89

0.00

0.64

0.55

0.22

1.25

0.00

0.00

0.71

0.52

0.39

0.17

0.69

0.75

0.00

1.98

0.01

0.16

0.08

0.32

0.52

0.00

0

$0.00 \quad 0.00$

0.00

0.00

0.00

0.01

0.38

$\begin{array}{rrrrrrr}0.97 & -0.97 & -0.92 & 0.97 & 0.12 & -0.36 & 0.83 \\ 0.97 & 0.23 & -0.64 & 0.96 & 0.18 & 0.99 & 0.93 \\ 0.98 & 0.99 & 0.99 & 0.99 & 0.14 & 0.98 & 0.83 \\ 0.67 & 0.33 & 0.29 & 0.68 & -0.60 & 0.79 & 0.62 \\ 0.57 & 0.56 & 0.52 & 0.56 & -0.26 & 0.79 & -0.01 \\ 0.74 & 0.85 & 0.80 & 0.49 & 0.26 & -0.99 & -0.91\end{array}$

\subsection{4}

0.91

0.87

$-0.24$

$-0.10$

0.74

0.26

$-0.99$

$-0.91$

Note: For the model variant without an operative bank capital requirement $\left(\phi^{\prime \prime}=0\right)$, the Table shows moments of HP filtered model variables, computed at the posterior mode of the estimated parameters. The bank capital ratio is expressed in factional units. The loan rate spread is expressed in fractional units per annum. Other variables are normalized by steady state values. Col. (1) assumes all 11 structural shocks and measurement error. In Cols. (2)-(9), subsets of shocks are assumed in isolation, without measurement error (model not re-estimated). Col. (2): just the 'non-banking' shocks, $\varepsilon_{t}^{n b k}$; Col. (3): just banking shocks, $\varepsilon_{t}^{b k}$. Col. (4): just Home and Foreign TFP shocks; Col. (5): just shocks to investment efficiency; Col. (6): just shocks to government purchases; Col.(7): just labor supply shocks; Col.(8): just loan loss shocks; Col. (9): just shock to required bank capital ratio $\left(\gamma_{t}\right)$. Col. (10) shows empirical moments (from Table 2). 


\begin{tabular}{|c|c|c|c|c|c|c|}
\hline ..GDP & Consumption & Investment & Employment & Loans & Bank Cap. & Loan \\
\hline US & US EA & "US" EA" & US EA & US ${ }^{\mathbf{E A}}$ & Ratio & Spread \\
\hline
\end{tabular}
(1) (2)
(3) (4)
(5) (6)
(7) (8)
(9) (10)
(11)

(12)

(a) Variance shares for baseline model, based on alternative data sets

(a1) Baseline data

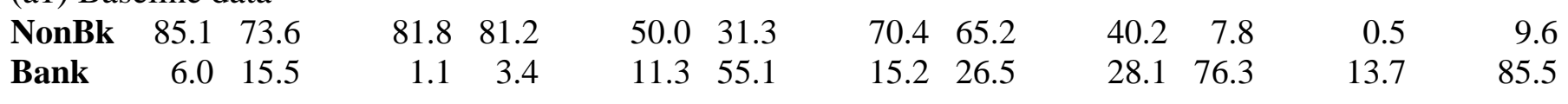

(a2) Loan rate spread replaced by loan officer survey spread measure

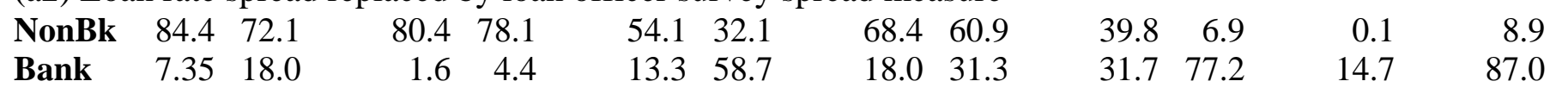

(a3) Loan rate spread replaced by Gilchrist-Zakrajsek excess bond premium

\begin{tabular}{|c|c|c|c|c|c|c|c|c|c|c|c|c|}
\hline NonBk & 82.3 & 68.7 & 78.7 & 76.8 & 51.0 & 28.5 & 64.38 & 56.1 & 36.1 & 6.3 & 0.09 & 5.2 \\
\hline Bank & 9.2 & 21.8 & 1.8 & 5.0 & 16.7 & 63.3 & 22.3 & 36.6 & 35.4 & 78.4 & 16.4 & 90.3 \\
\hline \multicolumn{13}{|c|}{ (a4) Total bank loans replaced by bank loans to non-financial business } \\
\hline NonBk & 83.3 & 67.9 & 75.4 & 82.9 & 53.3 & 31.4 & 69.6 & 49.9 & 18.5 & 1.0 & 2.69 & 2.69 \\
\hline Bank & 9.8 & 24.9 & 3.1 & 8.4 & 18.0 & 63.6 & 21.6 & 44.3 & 65.1 & 4.8 & 60.7 & 91.5 \\
\hline
\end{tabular}

(a5) US loans replaced by GZ business lending capacity; EA bank loans replaced by business loans

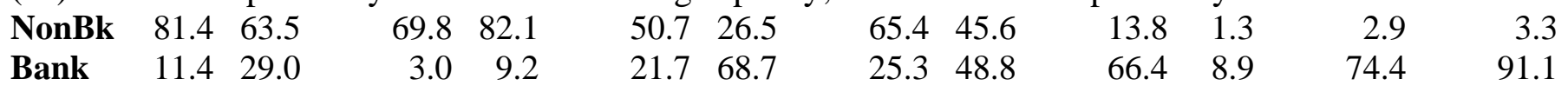

(b) Variance shares for model variant without operative bank capital requirement $\left(\phi^{\prime \prime}=0\right)$

$\begin{array}{lllllllllllll}\text { NonBk } & 95.4 & 91.8 & 89.1 & 92.4 & 73.0 & 79.4 & 93.9 & 93.9 & 66.0 & 59.3 & 21.8 & 0.01 \\ \text { Bank } & 0.00 & 0.00 & 0.22 & 0.38 & 0.00 & 0.00 & 0.00 & 0.00 & 11.8 & 30.5 & 21.1 & 0.02\end{array}$

Note: The rows labeled 'NonBk' and 'Bank' show \% shares of the variances of HP filtered variables (with measurement error) accounted for by the 'non-banking' shocks $\left(\varepsilon_{t}^{n b k}\right)$ and by the banking shocks $\left(\varepsilon_{t}^{b k}\right)$, respectively. The decompositions are computed at the posterior mode of the estimated parameters. The variance shares are shown for the variables listed above Cols. (1)-(12). Cols. (1)-(2): US and EA GDP; Cols. (3)-(4): US and EA consumption; Cols. (5)-(6): US and EA investment; Cols. (7)(8): US and EA employment; Cols. (9)-(10): US and EA loans; Col. (11): bank capital ratio; Col. (12): Loan rate spread.

Panels (a1)-(a5) pertain to estimates of the baseline model, with different data sets. Panel (a1) uses the baseline data set. In Panels (a2)-(a5), the baseline measures of banking variables are replaced by alternative measures. Panel (a2): baseline loan rate spread replaced by 'net percentage of banks increasing spreads of loan rates over cost of funds' from the US senior loan officer opinion survey, SLOOS. Panel (a3): baseline loan rate spread replaced by the Gilchrist and Zakrajsek (2011a) excess bond premium series. Panel (a4): the baseline loan series for US and EA replaced by loans to the non-financial business sector. Panel (a5): baseline US loan series replaced by US ‘business lending capacity’ measure of Gilchrist and Zakrajsek (2011b); baseline EA loan series replaced by EA bank lending to the non-financial business sector.

Panel (b) considers a variant of the model without an operative bank capital requirement $\phi "=0$ (the variant is estimated using the 12-variables baseline data set).

The model is re-estimated for each of the datasets/model variants considered in this Table. 
Figure 1. Time series used in estimation
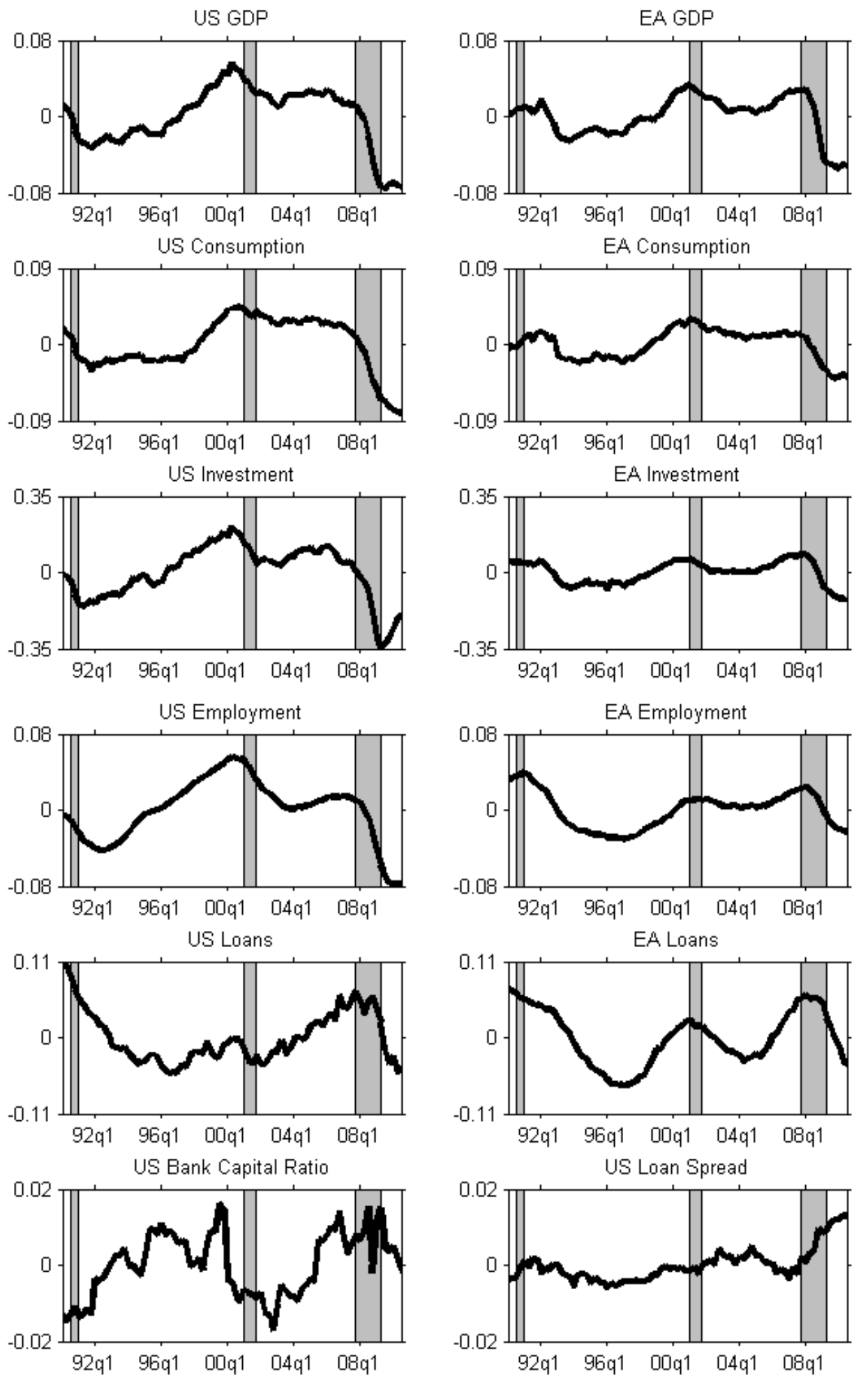

Note: The Figure shows the time series used in estimation. Bank capital ratio and loan spread (p.a.) are demeaned. Other variables are logged and detrended. Shaded areas indicate US recessions (NBER dates). 
Figure 2. US and EA loan rate spreads

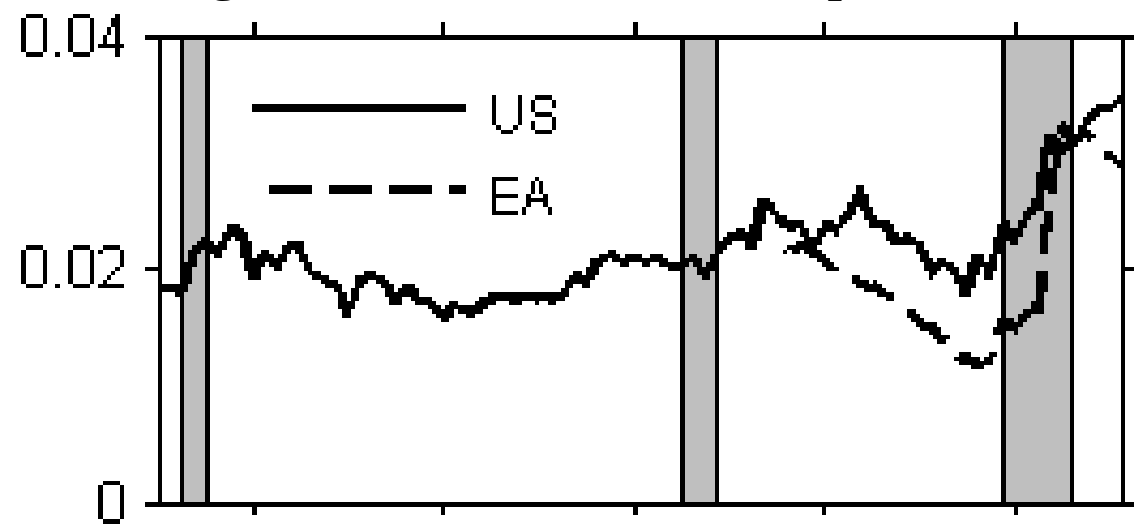

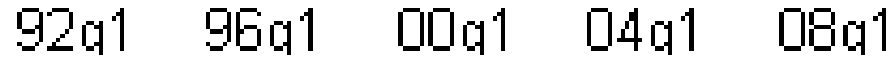

Note: Loan spreads (p.a.) are not demeaned. Shaded areas: US recessions (NBER dates).

Figure 3a. US bank capital, loan spread and SLOOS spread measure

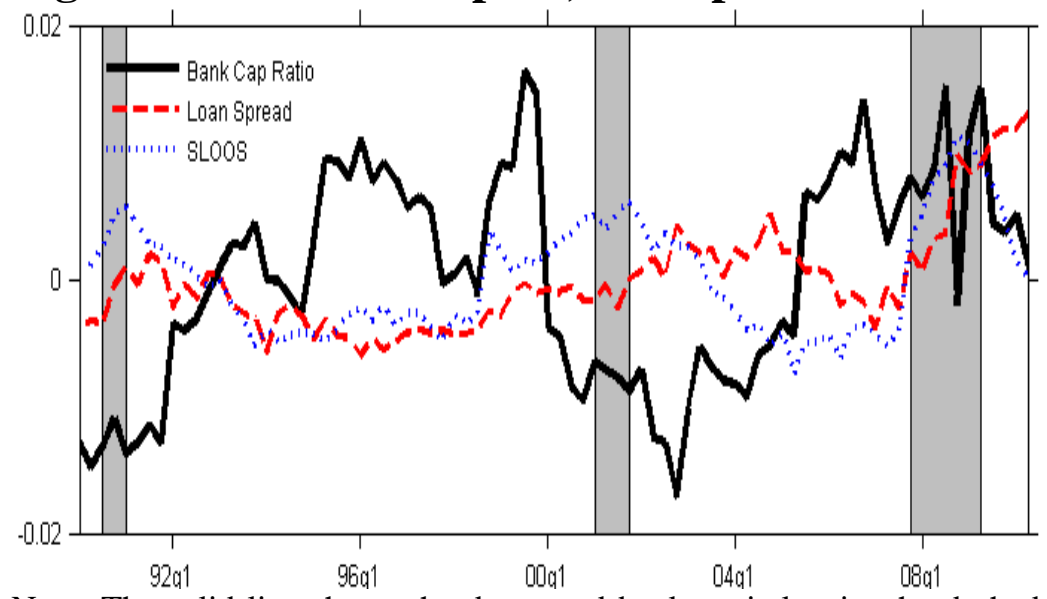

Note: The solid line shows the demeaned bank capital ratio; the dashed line shows the demeaned loan spread; the dotted line shows a survey-based measure of the net percentage of banks increasing spreads (from Survey of Senior Loan Officers Opinion Survey, SLOOS). Shaded areas: US recessions (NBER dates).

Figure 3b. US bank capital and Gilchrist-Zakrajsek (2011a) bond premium

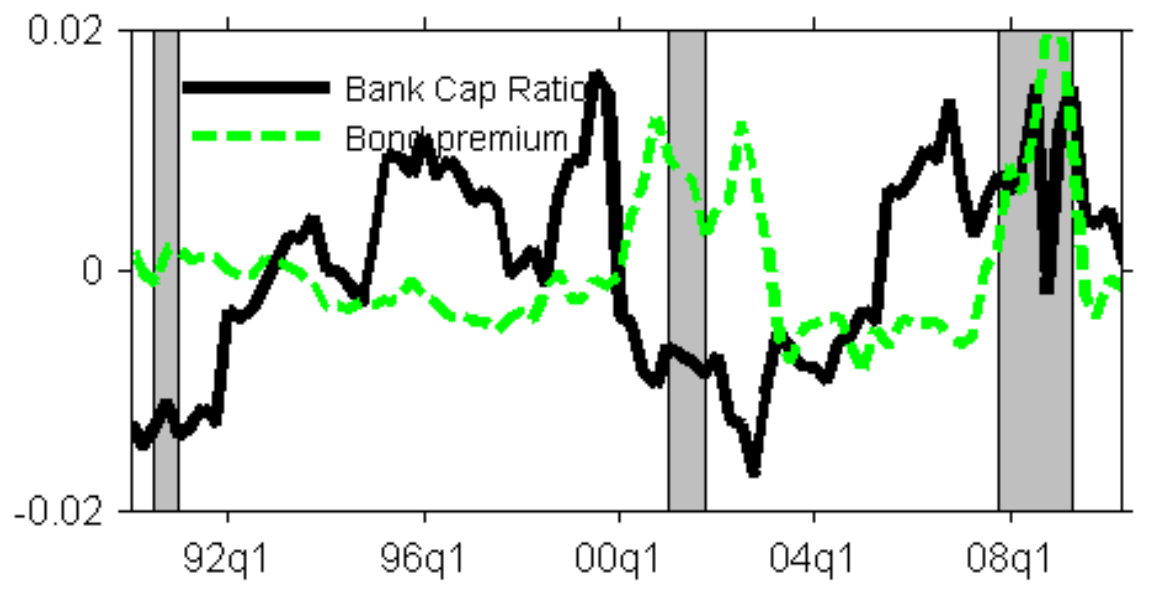

Note: The solid line shows the demeaned bank capital ratio; the dashed line shows the demeaned excess bond premium of Gilchrist and Zakrajsek (2011a). Shaded areas: US recessions (NBER dates). 
Figure 4. Historical decompositions (baseline estimation)
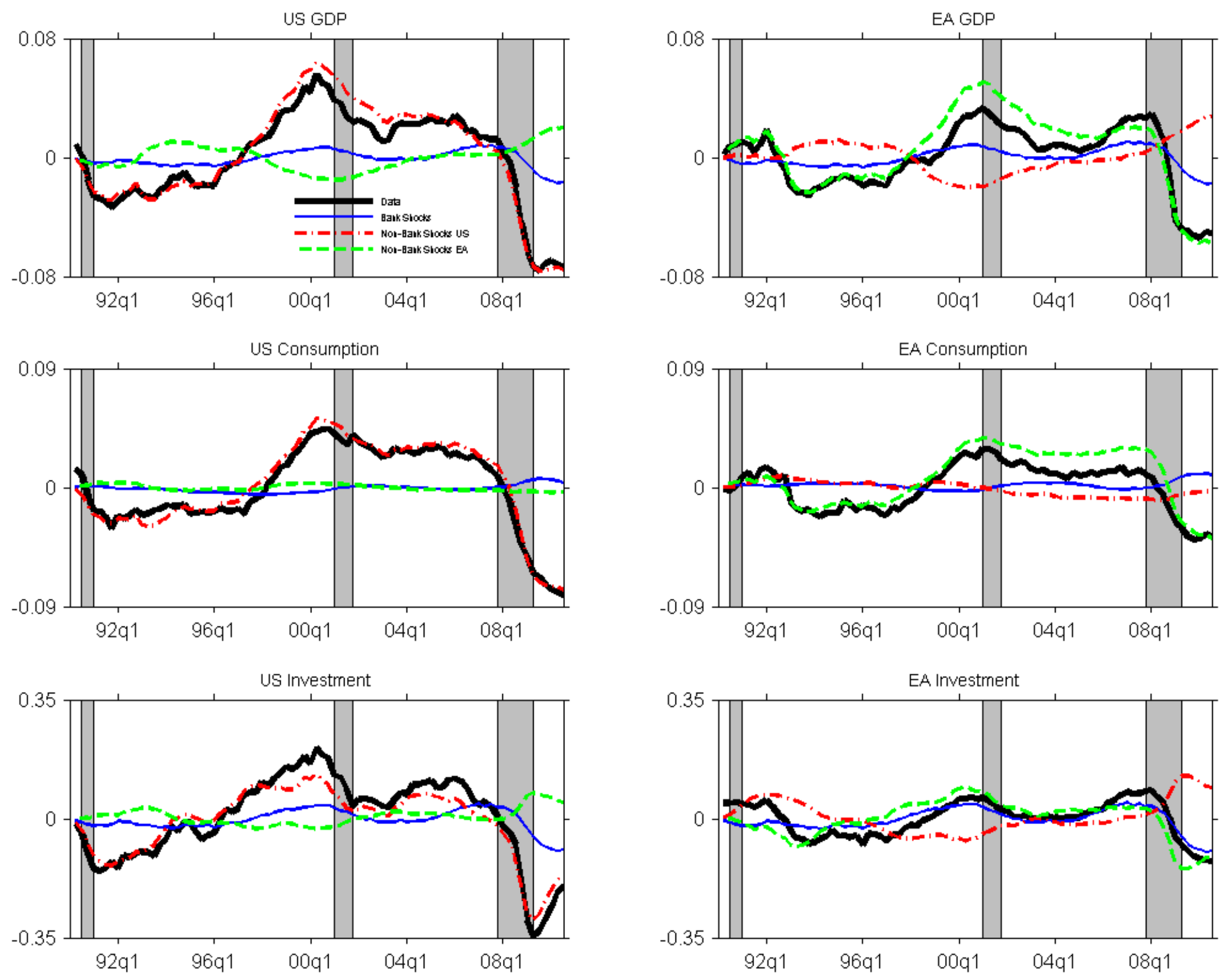
Figure 5a. US commercial banks: total loans, business loans and business lending capacity

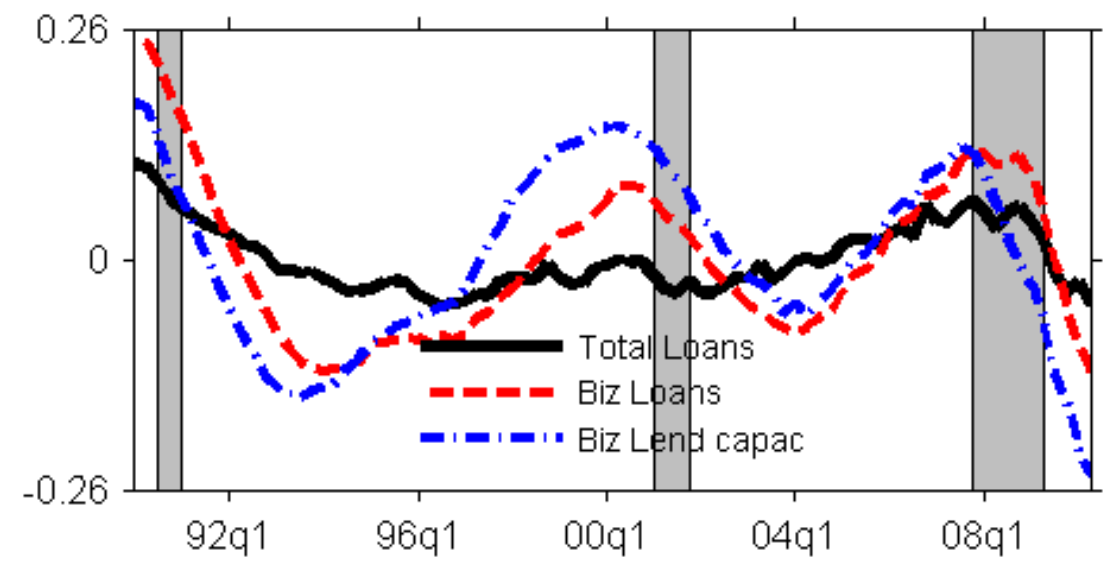

Note: The solid line shows total US bank credit (baseline measure); dashed line: business lending; dashed-dotted line: US business lending capacity (Gilchrist and Zakrajsek (2011b). All series are linearly detrended in log form. Shaded areas: US recessions (NBER dates).

Figure 5b. EA banks: total loans and business loans

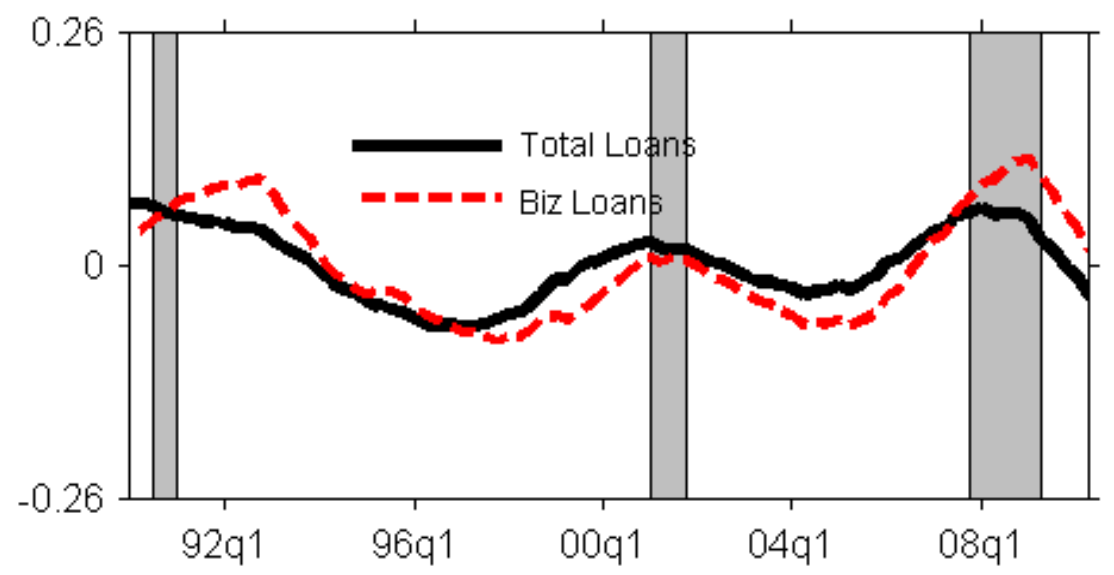

Note: The solid line shows total EA bank credit (baseline measure); dashed line: loans to non-financial corporations. Both series are linearly detrended in log form. Shaded areas: US recessions (NBER dates). 